\title{
Relationship between Economic Growth External Debt: Application to Turkey ${ }^{1}$
}

\author{
Hüseyin USLU²
}

\begin{abstract}
In this study, the effects of foreign debt on economic growth in Turkey's economy are investigated with contemporary time-series techniques for 1970-2016 periods. In the study, the stationarity of the series is examined by $\mathrm{ADF}$ and PP unit root tests and the series were found to be stationary at different levels. The existence of cointegration relationship between the series is examined by the Bounds Testing method and it is determined that external debt and economic growth move together in the long run. In the long-run analysis carried out by ARDL method, it is found that $1 \%$ increase in fixed capital stock, labor force, external debt stock and human capital enhance national income by $0.31,0.27,0.13$ and $0.46 \%$, respectively. Error correction mechanism of the model operates, that is, the outcomes are reliable. Causality relationships between the series are examined by TodaYamamoto causality test and it is found that one-way causality relationships exist from labor and external debt to economic growth. Also in this test; one-way causality relationships are found from the labor force to the fixed capital stock and human capital and from the external debt stock to the human capital.
\end{abstract}

Key Words: External Debt, Economic Growth, Bounds Testing, ARDL

\section{D1ş Borç Ekonomik Büyüme İlişkisi: Türkiye Uygulaması}

Öz

Bu çalışmada, Türkiye ekonomisinde dış borçların ekonomik büyüme üzerindeki etkileri 1970-2016 dönemi için güncel zaman serisi teknikleriyle araştırılmıştır. Çalışmada serilerin durağanlığ1 ADF ve PP birim kök testleriyle incelenmiș ve serilerin farklı derecelerde durağan oldukları görülmüștür. Seriler arasında eşbütünleșme ilişkisinin varlı̆̆ı Sınır Testi yöntemiyle incelenmiş ve dış borçlanma ile ekonomik büyümenin uzun dönemde birlikte hareket ettikleri belirlenmiştir. ARDL yöntemiyle gerçekleştirilen uzun dönem analizinde Türkiye’de milli geliri; sabit sermaye stokundaki \%1'lik artışın ortalama \%0.31, işgücündeki $\% 1$ oranındaki artışı $\% 0.27$, dış borç stokundaki $\% 1^{\prime}$ lik artışı $\% 0.13$ ve beşeri sermayedeki \%1 oranındaki artışı \% 0.46 oranında artırdığı tespit edilmiştir. Modelin hata düzeltme mekanizması çalışmaktadır ve elde edilen bulgular güvenilirdir. Seriler arasındaki nedensellik ilişkileri TodaYamamoto nedensellik testiyle incelenmiş ve işgücü ve diş borçlardan ekonomik büyümeye doğru tek yönlü nedensellik ilişkilerinin var olduğu tespit edilmiştir. Bu testte ayrıca; işgücünden sabit sermaye stoku ve beşeri sermayeye ve diş borç stokundan beşeri sermayeye doğru da tek yönlü nedensellik ilişkileri bulunmuştur.

Anabtar Kelimeler: Dış Borçlanma, Ekonomik Büyüme, Sınır Testi, ARDL

\section{Atıf İçin / Please Cite As:}

Uslu, H. (2021). Relationship between economic growth external debt: Application to Turkey. Manas Sosyal Arastermalar Dergisi, 10(1), 272-294.

Geliş Tarihi / Received Date: 07.02.2020

Kabul Tarihi / Accepted Date: 24.09.2020

\footnotetext{
1 This study is derived from the master's thesis entitled "Relationship between Economic Growth External Debt: Application to Turkey" prepared by the author in the Department of Economics, Institute of Social Sciences, Erciyes University.

2 Osmaniye Korkut Ata University, Faculty of Economics and Administrative Sciences, Department of Business Administration, h.uslu80@hotmail.com

iD ORCID: 0000-0002-2642-1175
} 


\section{Introduction}

Because of unbalanced distribution of resources among the countries, development differences between the countries and developing international relations, the domestic resources of the countries may be insufficient in the financing of economic growth and development. The need for foreign borrowing of developing countries may increase gradually due to the inability to meet the investments from domestic sources required in order to accelerate economic growth in these countries. This need is also the case for Turkey's economy. Especially after 1950, Turkey has tended to seek external resources and foreign borrowing by increasing external debt opportunities with fundamental changes in economic policies on foreign direct investment, external debt and foreign credits in order to sustain the economic growth and development goals.

National resources used in financing economic growth and development, namely domestic savings, in both developed and developing countries are of great importance. When these are not enough, external saving, that is foreign debt, comes into play. Therefore, internal and external savings can be seen as the source of economic growth. In this context, the insufficiency of domestic savings to generate economic growth and development, the lack of effective methods in tax collection, the low level of exports and the low income of tourism make countries in search of new resources, and in such cases, external borrowing becomes inevitable (Bilginoglu, \& Aysu 2008, p. 1). Especially large-scale problems like war, economic crisis and natural disasters further increase the need of countries for foreign aid and foreign borrowing.

External borrowing, which is defined as the funding of the state or a public institution from external sources (Evgin, 2000, p. 15), has been used extensively especially in developing countries in order to continue economic development processes. In this sense, due to the low domestic savings in developing countries, capital can be seen as a scarce production factor (Karagol, 2014, p. 6). In addition, developing countries can meet the need of investment goods to make the necessary investments through imports. As a result of the low export revenues that will cover the import expenses, these countries may face a foreign currency bottleneck and tend to external borrowing.

It can be expected that the foreign debts, which provide additional resources to the country from the moment they are received, will increase the amount of capital that forms the basis of economic growth and development if used in productive areas. In this context, investments will be increased by increasing the amount of capital, and economic growth and development will be accelerated (Panizza, Sturzenegger, \& Zettelmeyer, 2010, p. 2). Countries may remain in a difficult situation if foreign debt is not used in productive areas. Especially when foreign debt principal and interest payments increase more than the increase in national income, it is inevitable to go back to borrowing. As a result of this situation, which requires the outflow of resources from the country, the debt burden of the country rises, the growth slows down and therefore the welfare level decreases.

In this study; effects of external debt on economic growth during the 1970-2016 period in Turkey are examined theoretically and empirically. The study is expected to generate empirical evidence found by contemporary techniques to theoretical discussions on the effects of external borrowing on economic growth. Unlike similar studies in the literature, the fact that Bounds Testing is performed to determine the long-term status of the variables, that the long and short-term analyzes between the variables are performed with a dynamic and contemporary method such as ARDL, that the causality relationships between the series are performed employing a method using the level values of the series such as TodaYamamoto which consequently allows more information in the analysis and that the dataset covers a newer period distinguishes the study from its counterparts. The study is thought to add depth to the literature in this direction.

In the second part of the study following the introduction; a theoretical framework on external borrowing and economic growth is established. In the third part; the reasons why developing countries need external resources are identified. Then, various methods used in determining and calculating the amount of resources required for development and various ratio analysis (external debt indicators) used in measuring foreign debt payment capacity are explained. Historical development process of Turkey's external debt is investigated. In this context, external debt and economic growth in Turkey are demonstrated with the help of charts and graphs. In the fourth section; the literature review summaries about the topic are presented, in the fifth section; the external debt-economic growth relationship is analyzed econometrically. The study is completed with results and suggestions. 


\section{Theoretical Framework of the Relationship between External Debt and Economic Growth}

The money that governments (Ministry of Treasury or Undersecretariat of Treasury), other official institutions (Municipalities, Public Economic Institutions etc.), private companies or financial institutions (Banks etc.) receive from Treasuries or financial institutions of other countries (Banks, Exchanges, etc.) to pay back at the end of a certain time with interest is called external debt. Briefly, foreign debt is the credits, bond and bill received by individuals or organizations residing at home country from people or institutions residing abroad (Evgin, 2000, p. 15). According to the World Bank, a country's external debts are the sum of the short, medium and long term obligations that is provided with an internationally valid contract from individuals or institutions living in other countries (World Bank, 2018).

Until 1960s, while interstate aids were sufficient, these aids started to be insufficient with the increasing needs in the following periods and countries started to borrow significant amounts from each other. Thus, the share of foreign loans, bonds and bills sold in other countries in the international capital mobility began to increase. After all these developments, the concept of foreign aid has been replaced by the concept of foreign debt (Kirci, Cevik, \& Cural, 2013, p. 116). Over the course of time, banks, financial intermediaries and stock exchanges have also been included among external lenders. Stock exchanges are included in this process as the secondary market where bills and bonds issued by the country's treasuries and other institutions are traded.

World Bank takes two criteria into account when classifying countries according to their external debt: the ratio of the present value of the external debt service to the gross national income (PV/GNP) and the ratio of the present value of the foreign debt service to the total of exports and workers' income (PV/XGS). According to these criteria, the countries having PV/GNP $>80 \%$ or PV/XGS $>220 \%$ are accepted as heavily indebted, $48 \%<\mathrm{PV} / \mathrm{GNP}<80 \%$ or $132 \%<\mathrm{PV} / \mathrm{XGS}<220 \%$ are as moderately indebted and $\mathrm{PV} / \mathrm{GNP}<48 \%$ or PV/XGS $<132 \%$ are as low-indebted (Ozyildiz, 2017, p. 24-25). At this point, the following criteria can also be considered; World Bank accepts countries with an external debt stock to GDP ratio between $30 \%$ and $50 \%$ as moderately indebted and countries with more than $50 \%$ as a highly indebted. According to World Bank and the IMF, the ratio exceeding $50 \%$ is considered dangerous for countries (Evgin, 2000, p. 10) and it is considered that countries face the risk of economic crisis. The ratio of total external debt stock to exports is important in terms of indicating the country's foreign exchange revenues and foreign debt payment capacity (Altin, 2003, p. 75). While calculating the export data, total goods and services are included. It is accepted that if this ratio is between $165 \%$ and $275 \%$, the country is moderately indebted and if this ratio exceeds $275 \%$, the country is over-indebted (World Bank, 1990, p. 24). In fact, the IMF considers the ratio over $200 \%$ as a signal of danger (IMF, 2018). The ratio of total external debt interest service to exports is used to measure the cost of foreign debts and it is decided that the country is moderately indebted when the ratio is between $12 \%-20 \%$ and highly indebted when above $20 \%$ (Aysu, 2011, p. 32). Similarly, the ratio of international reserves to external debt stock and the ratio of foreign debt stock to tax revenues are also important for the sustainability of foreign debts of countries.

The negative difference between budget revenues and budget expenditures constitutes budget deficits. Classical economists argued that budget expenditures should not be more than budget revenues, that is, the budget should be equivalent. Keynes, on the other hand, stated that states should apply expansionary fiscal policies at the expense of budget deficits in order to accelerate the reestablishment of the economic balance, especially in times of economic crisis (Kogar, 1996, p. 301-302). This recipe, proposed by Keynes for difficult times, has become a habit in the states and especially some countries have become constantly deficit-giving. In this case, the internal and external debt stocks of the countries have increased rapidly over time, which triggered the debt crisis seen in Latin America and Turkey in the 1980s.

An important point here is the fact that the public borrowing from the domestic market will reduce the financial resources available in the country and increase their interest rates, which will increase the cost of private sector investments and therefore the private sector, will give up some investment expenditures. In order for this effect, called the Crowding Out, (Kesbic, Dundar, \& Devrim, 2016, p. 60) not to occur, it is beneficial for the public to meet the budget deficits with the funds it will obtain from the external market, not from the domestic market. 
The proportional increase in real GDP, which is the monetary value of all goods and services produced in a certain period within the borders of a country, calculated with the prices of a fixed year, is called economic growth (Parasiz, 2008, p. 71). There are also economists who prefer to measure economic growth with real GDP growth per capita (Lindgren, 2008; Jones, 2016, p. 6; Brueckner, \& Lederman, 2017 , p. 2). On the other hand, there are economists who define economic growth as a continuous expansion of potential production, which is measured by an increase in real gross domestic product over a certain period of time (Mohamed, 2014).

Economic growth, which can also be defined as the continuous increase in the amount of goods and services produced, is the most important indicator of the increase in welfare in the countries (Elmas Arslan, 2013, p. 46). Thanks to economic growth, employment increases, goods and services produced rise and national income per capita goes up. All of these enable people to meet their needs more easily and increase the level of benefits and well-being they achieve by consuming more goods and services.

The most important sources of economic growth are the increase in labor force and investment (machinery, equipment, factory, etc.), new natural resource discovery, technological progress and increase in productivity. In the Neoclassical Growth Model developed by Solow (1956), it is based on a production function of the Cobb-Douglass type (Jones, 2007, p. 23-50):

$$
Y=A K^{\alpha} L^{\beta}
$$

Here, $Y$ is Real GDP (production), A is exogenous factors affecting growth, including technology, $K$ is capital stock (amount of machinery and equipment, infrastructure, superstructure etc.), $L$ is labor force, $a$ is capital stock elasticity of production and $\beta$ is labor force elasticity of production. According to this model, increases in capital stock and labor force will raise production and economic growth. If the external borrowings are used to increase capital stock of the country, economic growth will go up. This case can be seen in Figure 1 .

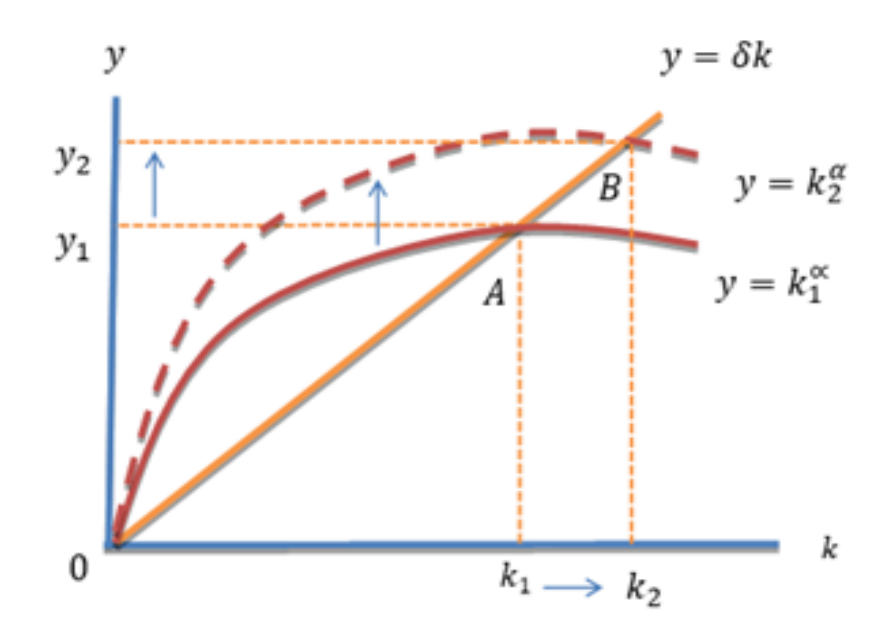

Figure 1. Solow Growth Model: Impacts of Increases in Capital Stock

Source: Jones (2007, p. 22-26)

As it is shown in Figure 1, if fixed capital stock per capita can be shifted from $k_{1}$ to $k_{2}$ by directing external borrowings to investment expenditures, then real production could rise from $y_{1}$ to $y_{2}$ and thus the economy would grow.

If one of these factors is kept constant while only the other (e.g. capital stock) is constantly increased, the economy will grow to a certain level, then it will come to a steady state balance and growth will stop. In this model, Solow (1956) considered the technology completely exogenous and compared it to an apple falling from the sky (Erdogan, \& Canbay, 2016, p. 32). In the Endogenous Growth Model developed by Romer (1986) and Lucas (1988), technological progress has been included in the production function through human capital, and it is stated that as human capital develops, economic growth will last forever. Explaining Endogenous Growth Model again with the help of a Cobb-Douglass production function; 
$Y=K^{\alpha} H^{\beta}$

Here, $H$ is human capital equipped with knowledge (education, experience), health and technology (Guvel, 2011, p. 106). In the Endogenous Growth Model, the production function is a positive sloped, linear function because in this model there is no diminishing return on labor. The reason for this is that human capital in this model is constantly being improved through education, research and development (R\&D), technological progress, experience and health expenditures. Therefore, increases in capital stock in the Endogenous Growth Model will continuously increase economic growth. So, if the debts taken from abroad can be used in the development of human capital (education, health, etc.) and capital stock in the country, it will have a positive contribution to the economy and there will be no problems in the payment of debts in the future. The amount of capital in the economy determines the level of the product that can be produced and the level of the product determines the level of savings and investments, respectively. In this context, high savings increase the investment opportunity for new capital goods and increase the capital stock of the economy. Thus, as the amount of capital per labor unit increases, unit labor will become more efficient. Therefore, specialization and productivity increase will be achieved in the production process. It can be said that the contribution of capital accumulation on specialization is great. Because mass production will be realized by mechanization and this will increase productivity. In the Endogenous Growth Model, the effects of the increases in capital stock on economic growth can be examined with the help of Figure 2.

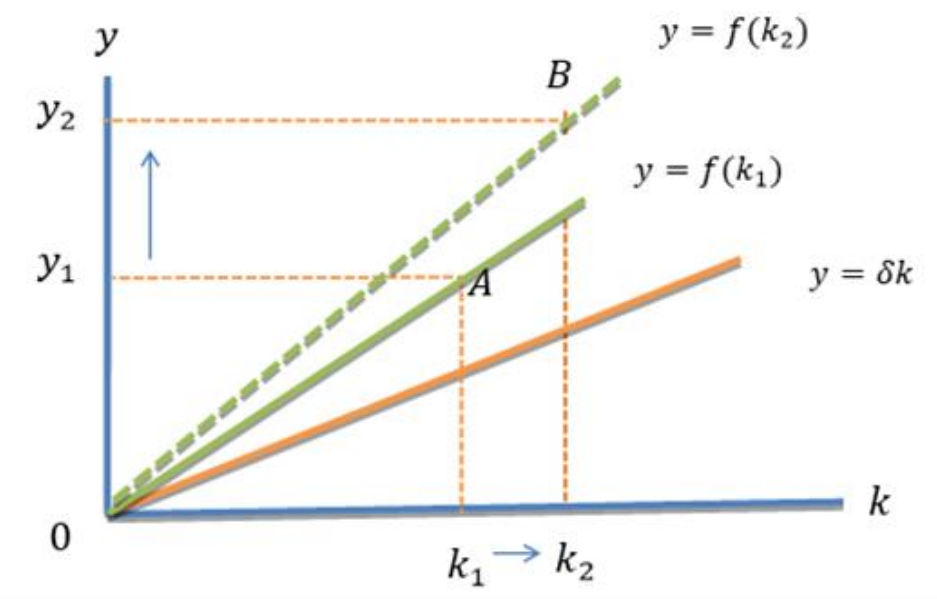

Figure 2. Endogenous Growth Model: Increase in Capital Stock.

Source: Guvel (2011, p. 103)

As seen in Figure 2; increased capital stock and human capital will also increase economic growth when external borrowings are used to make new investments domestically and to improve human capital. In the demand-side macroeconomic approach that started with Keynes (1936), national income is calculated using the expenditure method as in Equation (3) (Yildirim, Karaman, \& Tasdemir, 2009, p. 35):

$Y=C+I+G+X-M$

Here, $Y$ is Gross Domestic Product, $C$ is private (household) consumption expenditures, $I$ is private investment expenditures (investments of firms and housing acquisition of households), $G$ is the sum of public investment and consumption expenditures, $X$ is export and $M$ is import. While $C, I, G$ and $X$ contribute positively to the economy (injection), $M$ creates a leakage from economic flows and negatively affects national income (Mankiw, 2010, p. 29). At this point, it is of great importance in which areas the external debts will be used. If foreign debts taken are used to increase private consumption expenditures, this enables growth in the economy in the short term, but it causes an increase in the current account deficit and the country's foreign debt stock in the long term. If it is used to increase private investment expenditures, this enables the economy to grow both in the short term and in the long term. If it is used in public consumption expenditures and transfer payments, it enables short-term growth in the economy, but increases the country's foreign debt stock in the long term and damages economic growth. The fragility of the country's economy against external shocks rises. If it is used in public investment 
expenditures; it allows growth in the economy both in the short term and the long term. If it is used to support production of exported goods and exporters and exports can be increased, foreign currency inflows to the country, the current account deficit and the country's foreign debt stock are reduced, and ways to stable economic growth are opened in the long run. If it is used in buying luxury imported goods (such as technological expenditures that are not needed (such as mobile phones), luxury cars purchased by the public and households, etc.), it does not contribute to economic growth and cause more foreign currency outflow from the country, leading to an increase in the country's current account deficit and foreign debt stock, makes the country more vulnerable to economic shocks, seriously damages long-term economic growth. If foreign debts are used to purchase machinery-equipment and intermediate goods to increase the level of production in the country, it will contribute positively to economic growth in the long run even if it harms the economy in the short run.

As it is seen, where the foreign debt is used is as important as the amount of borrowings. If the foreign debts received are utilized efficiently, it will be possible to pay both the foreign debt principal and the interest accrued on these debts. An important point here is that the borrowings in foreign currency should be evaluated in productive areas that will earn as much foreign currency as possible. If the foreign debts taken are invested in non-export areas that do not earn foreign currency and are not productive, such as the construction sector, external debts may be harmful to the economy with the exchange rate risk in the long term, although it seems to revive the economy in the short term (Korkmaz, 2017). The effects of external debts on aggregate supply (AS) and aggregate demand $(A D)$ in the market can be examined with the aid of the $A D-A S$ model in Figure 3.

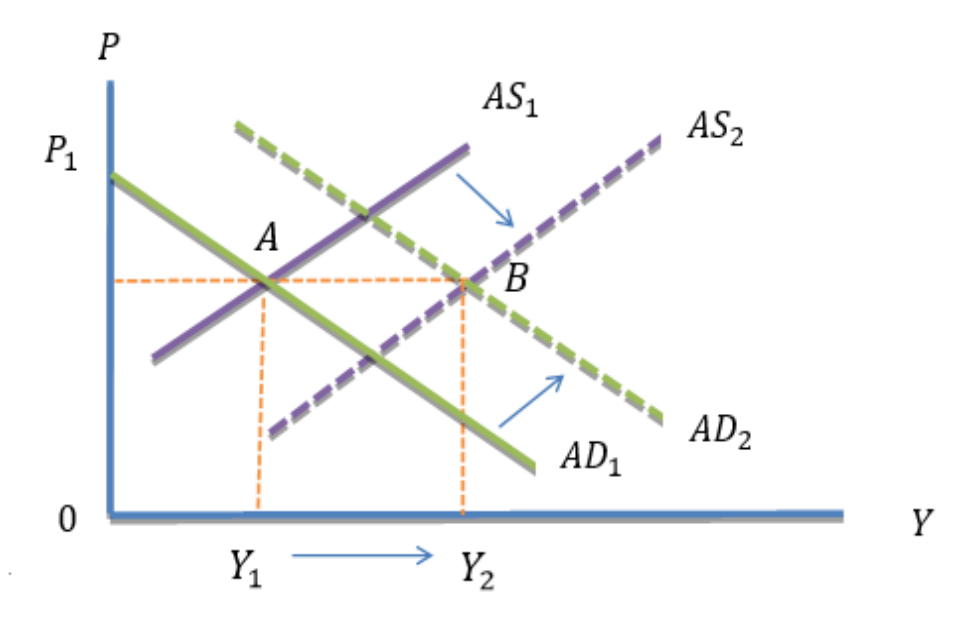

Figure 3: Reflection of External Debts on Markets

Source: Yildirim, Karaman ve Tasdemir (2009, p. 278).

In Figure 3, the economy is at equilibrium at point A initially. If the external debts received affect the total demand and the total supply in the same amount, these curves shift to the right in an equal amount and the real national income $(Y)$ increases without changing the prices level $(P)$. If total demand increases more than total supply, the general level of prices increases with real national income. If the total demands increases less than the total supply, real national income will increase and the general level of prices will decrease.

External borrowing is generally an injection for economy, and foreign debts that are not taken to pay past debts will accelerate economic activities in the country in the short term. However, in order for this effect to last for a long time, it is of great importance to utilize these resources in productive investment areas. Otherwise, there will be difficulties in the payment of foreign debts that increase with interest rates in the future periods. Considering that foreign debts are borrowed in foreign currency, the value of countries' debts in terms of national currency will increase much faster with increasing exchange rates. In such cases, the revenues that should be used to support the economic activities in the country will be spent for foreign debt payments, a significant leakage from the economy will occur and this will affect the economic growth negatively (Cogurucu, \& Coban, 2011, p. 136). 
While economic growth refers only to the increase in real GDP, economic development expresses the spread of economic growth to the base and increasing the general welfare of the people (Yuce, Akinci, \& Yilmaz, 2013, p. 113). If the foreign debts taken are used in production, education, health and other social investment expenditures, which will benefit the general public, they will positively affect development in the country. However, if the foreign debts taken will be used in inefficient investments or consumption expenditures, they will both increase the country's external debt stock, impairing the welfare of the society in the following years and make the country economically and politically susceptible to intervention by other states and international organizations, negatively affecting development.

\section{General Review of Turkey's External Debt and Economic Growth}

The first foreign debt in the Ottoman Empire was the debt worth of 3 million British gold (5.5 million Ottoman Liras) received from Palmer institution in London and Goldschmidt institution in Paris on November 24, 1854, as the costs of the Crimean War could not be met. Later, these debts continued and problems occurred in the payment of these debts over time. Some basic revenues of the country were mortgaged against these debts. The Düyun-u Umumiye-i Osmaniye Meclis Administration (Ottoman State Debt Administration Council) was established on December 20, 1881, so that foreign countries could collect their debts that could not be paid through these methods directly from the domestic market. The total external debt received during the Ottoman Empire was 347.3 million Ottoman Liras. The portion of the debt transferred to the Republic of Turkey was 105.5 million Liras (Ozdemir, 2009, p. 65).

Turkey has become, for the first time on August 4, 1958, unable to pay its external debt and declared moratorium. After that, the agreement for the restructuring and rescheduling of debts was signed with the Organization for European Economic Cooperation ${ }^{3}$ (OEEC) and the International Monetary Fund (International Money Found: IMF) for the first time. Turkey, having struggled to pay its external debts in the times of internal strife and chaos experienced in 1977-1978, has signed agreements with OECD member countries again for the rescheduling of $\$ 1.3$ billion foreign debt in May 20, 1978. The third agreement signed with OECD member countries on July 19, 1979, to delay $\$ 1.2$ billion of external debt and the fourth delay agreement signed with Citicorp on September 26, 1979, for $\$ 2.2$ Billion debt. The fifth delay agreement on May 30, 1980 for $\$ 1.4$ billion debt and the sixth delay agreement on July 23, 1980, for $\$ 3$ billion signed with OECD member countries (Ozyildiz, 2017, p. 22).

Turkey, for many years, had used project loans to finance domestic investment and refrained from using program credits. Such needs were met by domestic borrowing. With the Decision No. 32 (CBRT, 1989) on the Protection of the Value of the Turkish Currency, adopted on 7 August 1989, government and other institutions that did not want to get stuck in the domestic borrowing market started borrowing from the foreign markets with the beginning of freedom in the capital markets. The values of the external debt stock of Turkey in 1970-2017 period is seen in Figure 4.

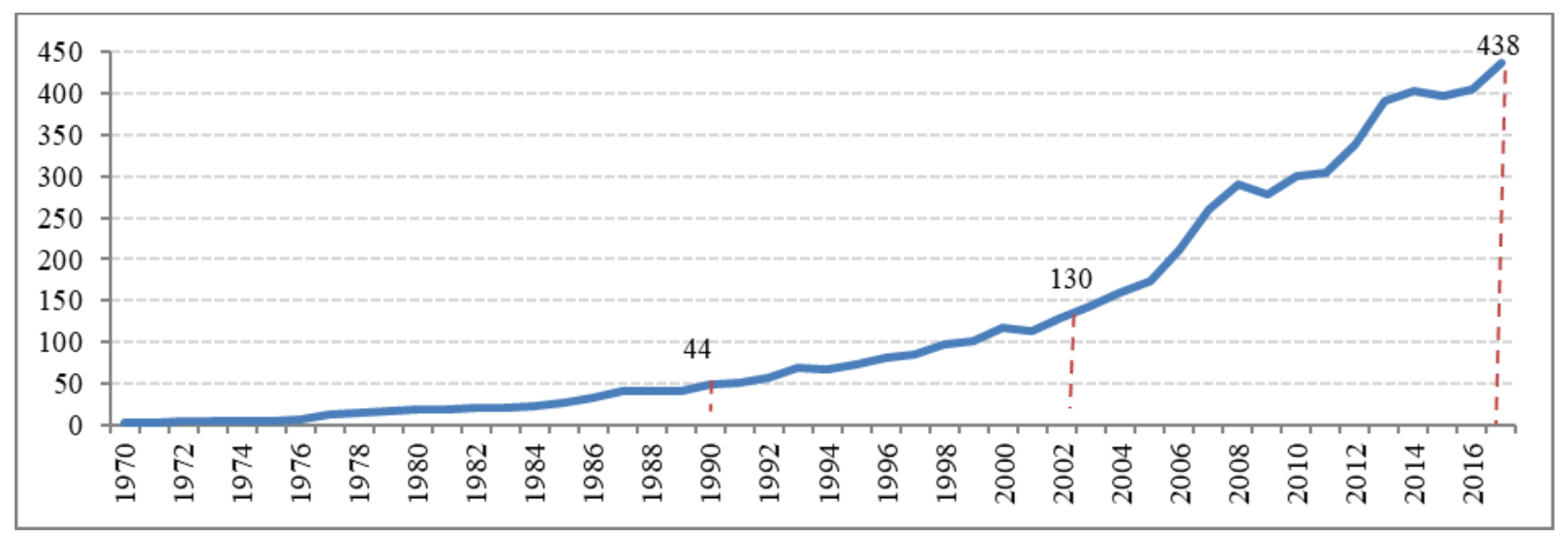

Figure 4. External Debt Stock of Turkey

Source: World Bank (2018a).

\footnotetext{
${ }^{3}$ Under the Marshall Plan developed by the United States (USA), this organization, which was founded in 1948 for the purpose of reconstructing Europe which was devastated in World War II, was later renamed the Organization for Economic Co-operation and Development (OECD) in 1961. Today, there are 34 countries participated in OECD, one of which is Turkey (Ministry of Culture and Tourism, 2018).
} 
As it is seen in Figure 4, external debt of Turkey, which was 44 billion Dollars in 1989 and 130 billion Dollars in 2002, quickly started to increase particularly post-2002 period and reached 438 billion dollars at the end of the first three quarters of 2017. Considering the fact that Turkey's GDP is predicted to be around 736 billion Dollars in 2017, the external debt stock to GDP ratio is approximately 59\%. Considering also that the countries are classified as highly indebted if the external debt stock to GDP ratio is over $50 \%$ according to World Bank's measures, Turkey is among heavily indebted countries. The annual change of external debts in Figure 4 can be examined with the help of Figure 5.

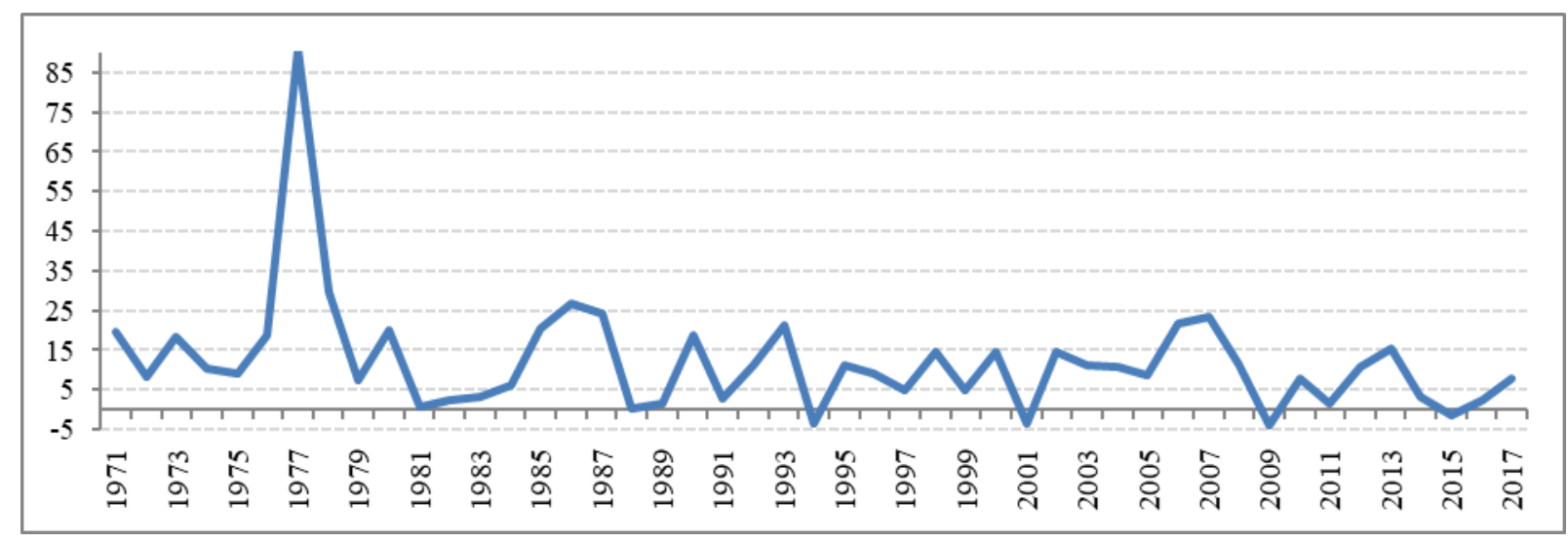

Figure 5. Annual Changes in Turkey's External Debt Stock (\%)

Source: World Bank (2018a).

Note: Horizontal line is annual average borrowing amount

As it can be seen in Figure 5, the periods that Turkey's external debt increased the fastest are 19771978, 1986-1987, 1993 and 2006-2007. From these years, 1993 is just before the 1994 economic crisis and one of the reasons for the 1994 crisis is thought to be raising external debt in this year. Excessive borrowing in 2006-2007 refers to borrowings made to accelerate economic growth. The path followed by the annual growth rate of Turkey's economy in 1970-2017 period is shown in Figure 6.

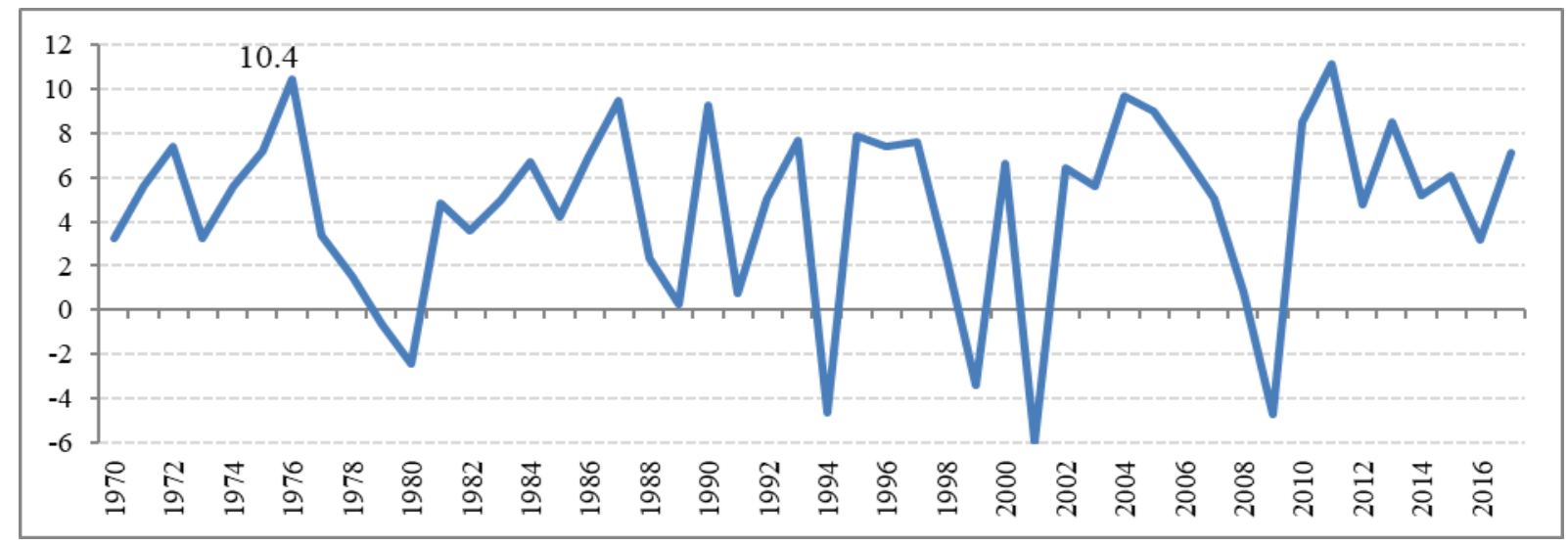

Figure 6. Economic Growth (\%)

Source: World Bank (2018b).

As seen in Figure 6; it is noteworthy that economic growth generally follows a fluctuating path in Turkey. It is beneficial for policy makers to take necessary precautions in this regard and strive to achieve more stable economic growth. The years when economic growth increased the most are 1976, 1987, 1990, 2004 and 2011. The contraction rates in the years when the economy contracts the most are $4.7 \%$ in 1994, $6 \%$ in 2001 and $4.8 \%$ in 2009. The interaction between economic growth and external borrowing can be seen in Figure 7. 


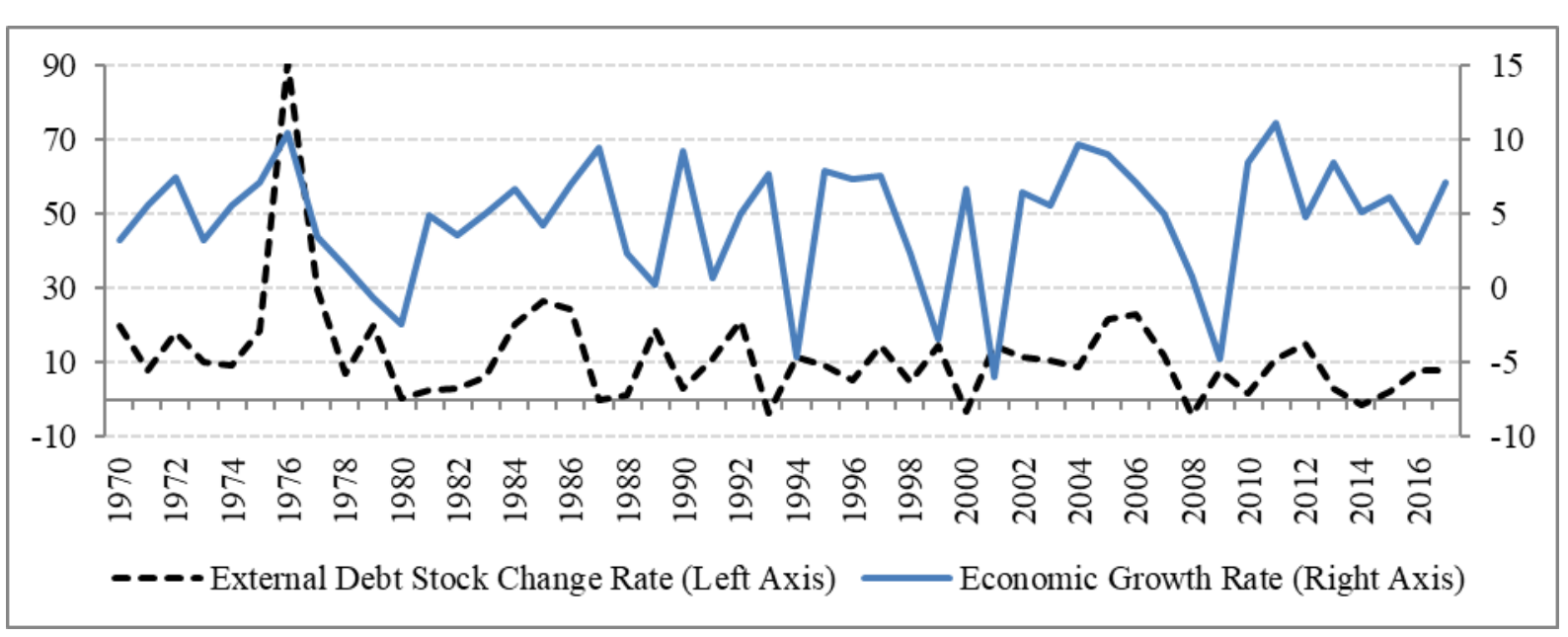

Figure 7. The Relationship between External Debts and Economic Growth in Turkey

Source: World Bank (2018a, 2018b).

Figure 7 shows a significant simultaneity between external debt and economic growth in Turkey's economy. Moving from here; Economic growth in Turkey can be said to be financed by external debt. Classification of Turkey's foreign debt by borrower is shown in Table 1.

Table 1. Classification of Turkey's External Debts by Borrowers (Billion Dollars)

\begin{tabular}{cccccccc}
\hline \multirow{2}{*}{ Years } & \multicolumn{2}{c}{ Public } & \multicolumn{2}{c}{ CBRT } & \multicolumn{2}{c}{ Private } & \multirow{2}{*}{ Total } \\
\cline { 2 - 6 } & Value & Rate & Value & Rate & Value & Rate & \\
\hline 1990 & 33.3 & 63.5 & 8.3 & 15.9 & 10.8 & 20.6 & 52.4 \\
1995 & 42.0 & 55.3 & 12.2 & 16.0 & 21.8 & 28.7 & 75.9 \\
2000 & 50.1 & 42.2 & 14.1 & 11.9 & 54.4 & 45.9 & 118.6 \\
2005 & 70.4 & 41.2 & 15.4 & 9.0 & 84.9 & 49.7 & 170.8 \\
2010 & 89.1 & 30.5 & 11.6 & 4.0 & 191.0 & 65.5 & 291.7 \\
2015 & 113.1 & 28.5 & 1.3 & 0.3 & 281.9 & 71.1 & 396.4 \\
2016 & 119.8 & 29.6 & 0.8 & 0.2 & 284.5 & 70.2 & 405.1 \\
2017 & 129.4 & 29.6 & 0.7 & 0.2 & 307.9 & 70.3 & 438.0 \\
\hline
\end{tabular}

Source: CBRT-EVDS (2018b).

Looking at the data in Table 1, 63.5\% of Turkey's external debt was owned by the public, $15.9 \%$ was by Central Bank and only $20.6 \%$ of it was by private sector in 1990 . This composition has changed in time and the share of public in external debt decreased to $29.6 \%$, of CBRT to $0.2 \%$ and of private sector increased to $70.3 \%$ in 2017. Information about Turkey's main external debt ratios are presented in Table 2.

Table 2. External Debt Ratios of Turkey (\%)

\begin{tabular}{cccccccc}
\hline Years & $\begin{array}{c}\text { External } \\
\text { Debt Stock } \\
\text { GDP }\end{array}$ & $\begin{array}{c}\text { External Debt } \\
\text { Stock / Goods } \\
\text { and Services } \\
\text { Export }\end{array}$ & $\begin{array}{c}\text { External Debt } \\
\text { Service / GDP }\end{array}$ & $\begin{array}{c}\text { External } \\
\text { Debt } \\
\text { Interest } \\
\text { Payments } \\
\text { /Export }\end{array}$ & $\begin{array}{c}\text { External Debt } \\
\text { Service / Foreign } \\
\text { Exchange } \\
\text { Incomes }\end{array}$ & $\begin{array}{c}\text { International } \\
\text { Reserves / } \\
\text { External Debt } \\
\text { Stock }\end{array}$ & $\begin{array}{c}\text { External Debt } \\
\text { Stock / Tax } \\
\text { Incomes }\end{array}$ \\
\hline 1990 & 33.4 & 245.4 & 37.7 & 26.3 & 258.9 & 15.4 & 283.8 \\
1995 & 44.4 & 218.8 & 50.3 & 20.5 & 223.9 & 18.8 & 311.5 \\
2000 & 43.4 & 220.0 & 50.4 & 24.7 & 258.5 & 20.1 & 256.5 \\
2005 & 35.0 & 164.7 & 42.9 & 12.1 & 194.6 & 30.2 & 213.1 \\
2010 & 39.3 & 190.6 & 46.7 & 10.3 & 221.5 & 28.6 & 200.9 \\
2015 & 46.7 & 197.6 & 48.7 & 7.0 & 205.8 & 27.9 & 253.0 \\
2016 & 47.8 & 213.8 & 55.8 & 10.2 & 249.3 & 26.1 & 255.3 \\
\hline
\end{tabular}

Source: World Bank (2018c, 2018d, 2018e, 2018f). 
As can be seen from Table 2, the ratio of external debt stock to national income in Turkey was $16.1 \%$ in 1970 , had increased over time and rose to $48.1 \%$ in 1987 . This ratio, which started to decrease afterwards, rose to $52 \%$ with the effect of the 1994 economic crisis and to $57.8 \%$ after the 2001 crisis. The ratio, which tended to decrease afterwards, started to increase again due to the 2008 global economic crisis and increased to $47.8 \%$ as of 2016 . Considering that the countries are classified as moderately indebted if this ratio is between $30 \%$ and $50 \%$ and highly indebted if the ratio is above $50 \%$ according to World Bank and the IMF, Turkey is a moderately indebted and is likely to be a heavily indebted country.

The ratio of external debt to total goods and services exports in Turkey was as quite high as $380.1 \%$ in 1971, has reached enormous amounts exceeding 500\% from 1977 to 1980 period, tended to decrease over time, decreased down to $170.9 \%$ in 1998 and increased again in 1999-2003 period. This ratio, which started to decrease after 2004, has increased again in 2016. Considering that the countries are classified as moderately indebted if this ratio is between $165 \%$ and $275 \%$ and highly indebted if the ratio is above $275 \%$ according to World Bank and the IMF, Turkey can be classified as a highly indebted country in 1970 's and moderately indebted in recent times.

Looking at Table 2 considering that the ratio of external debt stock to tax revenues exceeding $290 \%$ is a threshold value in terms of crisis risk for countries according to the IMF, this ratio was exceeded in the period of 1984-1989, 1994-1996 and 2001-2002 and the country experienced a significant problem in terms of external debts. This ratio, which started to decline in the post-2003 period, have begun to increase again after 2010 and exceeded $255 \%$ by the end of 2016, which indicates that governors of the economy should take measures in this regard.

\section{Literature Review}

A summary of the studies in the literature, in which the relationship between external debts and economic growth is investigated, is given chronologically. Lin and Sosin (2001) investigated the relationships between external debt and economic growth using panel data analysis for 77 countries, and found a negative and statistically significant relationship between external borrowing and per capita national income in African countries while determining negative and statistically insignificant relationship in Latin American countries and positive and statistically insignificant relationship in Asian countries. Kara (2001) stated in the paper, in which the effectiveness of the external debt based economic growth strategy implemented in Turkey after 1980 is examined by graphs and tables, that Turkey have usually purchased raw materials and consumption goods with it foreign borrowings, financed infrastructure investments having low return and, the worst of all, used for the payment of past debts whose due date arrived (refinancing purpose). Because of all of these, economic growth could not be promoted.

Kozali (2007) investigated the impacts of the external debt on economic growth in Turkey's economy, by using 1970-2005 period data, in the framework of Hakkio and Rush (1991) approach employing ADF, PP, KPSS unit root tests, Engle and Granger (1987) two-step cointegration test, Johansen cointegration test and Phillips-Hansen Fully Modified OLS method. At the end of the analysis; it is determined that external debt stock and debt service affect economic growth negatively in Turkey. Boopen, Kesseven and Ramesh (2007) investigated the relationships between external debt stock and economic growth in Mauritius with the help of error correction model using the data of 1960-2004 and found that external borrowing have negative effects on economic growth in both short and long run. It is also determined that public sector debts in this country have a crowding out effect on the private sector. Bilginoglu and Aysu (2008) examined the relationship between external debts and economic growth using 1968-2005 period data in Turkey with the help of ADF unit root test and regression analysis by OLS method. In the analysis; it is determined that the increase in the share of foreign debts in GDP negatively affects the national income and the effect is statistically significant. Human capital, fixed capital stock and population increases are found to impact national income in a positive and statistically reliable way. The effects of trade openness on national income are found to be positive but statistically insignificant. At the end of the study, authors stated that the conditions of the external debts and how they are utilized are of great importance in developing countries such as Turkey and such debts could be detrimental to the national income of the country unless they are well managed. Adegbite, Ayadi and Ayadi (2008) examined the economic effects of external debts using 1975-2005 period data for Nigeria employing linear and nonlinear models and determined that external debts affects economic growth positively and statistically significantly. The effects of external debts on primary deficit are found to be negative and statistically significant. 
Malik, Hayat and Hayat (2010) investigated the effects of external debt stock on economic growth by using ADF unit root test and OLS method for the Pakistan economy for the period of 1972-2005 and determined that external debt stock has a negative effect on economic growth. Cogurucu and Coban (2011) examined the relationship between external debt stock and economic growth in Turkey's economy during the period of 1980-2009 by ADF unit root test, Johansen cointegration test and OLS regression analysis. At the end of the analysis; it is determined that external debts and population increases affect economic growth in a negative and statistically significant way in Turkey. On the other hand, it is determined that trade openness have positive and statistically significant impact while investment and national education expenditures have positive but statistically insignificant impact on economic growth. In the Granger causality test; one-way causality relationships from economic growth to population growth and from fixed capital investments to economic growth is identified. At the end of the study, the authors emphasized that in order to increase the economic growth in the country, the necessary investments should be done with domestic resources and, for this, domestic savings should be increased.

Aysu (2011) analyzed the relationship between external borrowing and economic growth in Turkey by using 1980-2009 period data with ADF unit root test and OLS method and determined that external debt negatively affects economic growth in Turkey. The study also found that increases in fixed capital investments positively and statistically significantly affect economic growth. Ceylan and Durkaya (2011) examined the relationship between external debt and economic growth in Turkey by Engle and Granger cointegration test, TAR and M-TAR cointegration methods and reported that cointegration relationship between external borrowing and economic growth in Turkey is determined in all tests, the results of TAR test is more robust and the relationships between external debt stock and economic growth are asymmetric.

Gul, Kamaci and Konya (2012) investigated the impact of external debt on economic growth in Central Asian Turkish Republics and Turkey for the 1994-2010 period and estimated causality from external debt service to economic growth while could not determining causality relationship from economic growth to external debt service. Ejigayehu and Persson (2013) analyzed the relationships between external borrowing and economic growth with panel data analysis for the heavily indebted poor African countries with 1991-2010 data, and found that foreign debts negatively affect the economic growth of these countries. Daud, Ahmad and Azman-Saini (2013) investigated the effects of foreign debt on economic growth in Malaysia using the data from 1991:Q1-2009:Q4 period with ARDL method, and found that external debts positively affect Malaysia's economic growth.

Olcar (2013), in the paper that covered Turkey's foreign debt problems and the economic crisis caused by this problem through external debt ratios, determined that there is a close relationship between external debt stock and the 1994 and 2001 crisis happened in Turkey. Eratas and Basci Nur (2013) investigated the relationships between external debts and economic growth for countries of emerging market economies such as China, India, Brazil, South Korea, Indonesia, Turkey, Poland, Argentina, Mexico and South Africa using panel data analysis methods assuming cross-section dependence exists for 1990-2010 period and determined that foreign borrowing in these countries damaged economic growth in these countries. Dritsaki (2013) investigated the relationship between economic growth, exports and public foreign debt in Greece using the data of 1960-2011 with the help of Granger causality test and error correction model and found that these variables move together in the long term, that is, they are cointegrated, and that there is one way causality from exports to economic growth, from economic growth to public external debt.

Ozer (2014) examined the relationships between foreign borrowing and economic growth in Turkey's economy for 1980-2010 period with ADF unit root test, Granger causality test, Engle and Granger cointegration test and error correction model. At the end of the analysis; it is determined that there is a two-way causality relationship between economic growth and external borrowing, and the increase in foreign debts positively affects economic growth. From this result, it is stated that external borrowings efficiently utilized in Turkey and increased economic growth. Akan and Kanca (2015) investigated the relationships between external debt, economic growth and inflation in Turkey's economy for 1980-2013 period by ADF unit root test, Granger causality test and VAR based methods such as impulse-response functions and variance decomposition. After the analysis, one-way causality relationship from economic growth to inflation and external borrowing are determined, shocks that increased economic growth have a strong effect on external borrowing and changes in foreign debt have a significant effect on inflation rate. Gurdal and Yavuz (2015) examined the relationships between external debt and economic growth in 
Turkey for 1990:M1-2013:M12 period by Zivot-Andrews unit root test, Gregory-Hansen cointegration test and Hacker and Hatemi-J causality test and found that one-way causality relationship from economic growth to external debts exists. It is determined that increases in foreign debts affect economic growth in a positive and statistically significant.

Ijirshar, Joseph and Godoo (2016) investigated the relationships between foreign borrowing and economic growth in the Nigerian economy for the period of 1981-2014 and determined a statistically significant relationship between external borrowing and economic growth. The study also found that foreign debts increase economic growth and foreign debt service decreases it. Kutlu and Yurttaguler (2016) examined the relationships between foreign borrowing and economic growth in Turkey's economy using 1998:Q1-2014:Q2 period data by ADF and PP unit root tests, Johansen cointegration test and Granger causality test. In the study in which the series are found to be cointegrated, one-way causality relationship is also determined from the net foreign debt stock to economic growth. Kamaci (2016) analyzed the impacts of external borrowing on economic growth and inflation for Turkey and Central Asian Turkish Republics, namely Kazakhstan, Azerbaijan, Uzbekistan, Kyrgyzstan, Tajikistan and Turkmenistan, for 1995-2014 period annual data by panel causality and panel cointegration methods. In the study, Breitung panel unit root test, Pedroni panel cointegration test and Granger panel causality test are used. At the end of the analysis; one-way causality relationship from foreign debt to economic growth is determined, and no relation is found between foreign debt and inflation.

Jilenga, Xu and Gondje-Dacka (2016) investigated the relationships between foreign debt, foreign direct investment and economic growth, using data from the period of 1971-2011 for Tanzania, by Bounds Testing and ARDL methods, and found that foreign debt promotes economic growth in the long run and that foreign direct investment has a negative effect on economic growth. In the study, it is also revealed that there are no causality relationships between these variables. Agir (2016) analyzed the relationships between foreign borrowing and economic growth in Turkey's economy by linear and nonlinear asymmetric methods. At the end of the study; while no causality relationship can be found between external borrowing and economic growth according to the linear causality test, a causality relationship from negative external debt stock shocks to negative growth is determined in the asymmetric causality test. Nwannebuike, Ike and Onuka (2016) investigated the relationships between foreign debt and economic growth in Nigeria with the help of ADF unit root test, Engle and Granger cointegration test and error correction model for the period of 1980-2013 and determined that external debts have a negative effect on economic growth.

Sarac and Yucel (2017) examined the relationships between external debt and economic growth in Turkey's economy by threshold regression model for 2000:Q1-2016:Q3 period and determined that the level of external debt has negative impact on economic growth. Topal and Bostan (2017), in the study that examined the economic impacts of external debts for 1932-2016 in Turkey, found that 1\% increase in external debt decreases unemployment rate by $0.14 \%$ in the short run and $0.24 \%$ in the long run. In the study, the analysis was conducted by OLS, dynamic OLS, Fully Modified OLS, ARDL (Autoregressive Distributed Lags) and VECM (Vector Error Correction Model) methods. In Toda Yamamoto causality test, it is determined that there is a two-way causality relationship between external debt stock and unemployment rate. At the end of the study, the authors stated that external debts are not used efficiently in Turkey, this case also damages the sustainability of external debt and external debt stock should be decreased.

In the literature review; it is seen that the studies reached different results by using the same variables for the same country. The reason for this may be the use of different econometric methods or the difference in the periods used. On the other hand, the impact of external resources received by the public sector on economic growth may differ by country. This situation may arise from the development differences between countries, total debt stock and debt limits, or the use of the resources obtained. The vast majority of the literature examining the relationship between external debt and economic growth could not detect a significant relationship between these variables. In some of these studies, it is concluded that there is a mutual (two-way) relationship between these variables, and in some, there is oneway causality relationship, while in others there is no relationship between these variables. On the other hand, the number of studies that detect a significant relationship between the variables is extremely limited. It is evaluated that this study will contribute to the literature in terms of the data set and methods used. 


\section{Econometric Analysis}

\section{Data and Model}

In this study, to test the relationship between external debt and economic growth, Gross Domestic Product $(Y, \$)$ as dependent variable and Gross Fixed Capital Formation $(K, \$)$, population representing the labor force ( $L$, person), external debt stock (EDS, \$) and education expenditures $(H, \$)$ representing human capital as independent variables were used. Analyzes were carried out with the data of 1970-2016 period as this period is the widest time range that can be reached with the regular data set. The data were obtained from World Bank's website, necessary arrangements were made by us, and the natural logarithm of all series used in the analysis was taken. The purpose of taking the logarithm of the series is to eliminate the problem of heteroscedasticity that may arise in the analysis. In the selection of data and determining the econometric model to be use, Cunningham (1993), Karagol (2002), Bilginoglu and Aysu (2008) and Çögürücü and Çoban, (2011) studies were based. In the study; 5 dummy variables were used in order to be able to capture the impacts of the liberalization policy on 24 January $1980\left(D_{1980}\right)$, the freedom of capital movements (Decision 32, 1989; $\left.D_{1989}\right), 1994$ crisis $\left(D_{1994}\right), 2001$ crisis $\left(D_{2001}\right)$ and 2008 crisis $\left(D_{2008}\right)$. While creating dummy variables; while value of 1 is given continuously during and after the event for dummies whose impacts last forever, value of 1 is given in crisis periods and 0 in other periods. In the creation of the econometric model to be used in the study, the Cobb-Douglass production function in Equation (4) was used.

$$
Y=A K^{\alpha} L^{\beta}
$$

Taking the logarithm of both sides;

$$
\operatorname{Ln} Y=\operatorname{Ln} A+\alpha \operatorname{Ln} K+\beta \operatorname{Ln} L
$$

Here, $A$ is technology variable and included in the analysis by human capital (education, $H$ ), following Romer (1986) and Lucas (1988). With the addition of external debt stock variable, model is extended:

$\operatorname{Ln} Y=\operatorname{Ln} H+\alpha \operatorname{LnK}+\beta \operatorname{LnL}+\theta \operatorname{LnEDS}$

Demonstrating in econometric form, it becomes:

$$
L n Y_{t}=\alpha_{0}+\alpha_{1} \operatorname{LnK}_{t}+\alpha_{2} \operatorname{LnL}_{t}+\alpha_{3} \operatorname{LnEDS}_{t}+\alpha_{4} \operatorname{LnH}_{t}+u_{t}
$$

Adding dummy variables to the model, finally reached.

$$
\begin{aligned}
& L n Y_{t}=\alpha_{0}+\alpha_{1} \operatorname{LnK}_{t}+\alpha_{2} \operatorname{LnL}_{t}+\alpha_{3} \operatorname{LnEDS_{t}}+\alpha_{4} L n H_{t}+\alpha_{5} D_{1980}+\alpha_{6} D_{1989}+\alpha_{7} D_{1994}+\alpha_{8} D_{2001} \\
& +\alpha_{9} D_{2008}+u_{t}
\end{aligned}
$$

Here, $u_{t}$ is error term with constant variance and zero mean. $t$ is the time dimension.

\section{Unit Root Test}

In econometric analysis, it is necessary to determine the stationarity degrees of the series first, because while selecting the methods to be used in the later stages of the analysis, the stationarity degrees of the series should be examined. The most commonly used unit root test in econometric analysis is ADF test, in which the degree of influence of the value of the series in a particular $t-1$ period on the value in the $t$ period is examined (Tari, 2012, p. 417). The model of ADF unit root test with trend and intercept term developed by Dickey and Fuller (1981) for this purpose is:

$$
\Delta Y_{t}=\varphi_{0}+\varphi_{1} t+\sigma Y_{t-1}+\sum_{i=1}^{m} \gamma_{i} \Delta Y_{t-i}+e_{t}
$$

The hypotheses of ADF test are:

$H_{0}: \sigma=0$ Series has unit root and is not stationary

$H_{1}:|\sigma|<0$ Series does not have unit root and is stationary

After these tests, the series that is stationary at level values are called $I(0)$, stationary at first difference is called $I(1)$ and stationary at second difference is called I(2) (Gujarati, \& Porter, 2012, p. 759). In this study, stationarity of the series is tested by ADF and PP tests and results are presented in Table 3. 
Table 3. Results of Unit Root Test

\begin{tabular}{clccc}
\hline \multirow{2}{*}{ Variable } & \multicolumn{2}{c}{ ADF Test } & \multicolumn{2}{c}{ PP Test } \\
\cline { 2 - 5 } & Test Stat. & Prob. & Test Stat. & Prob. \\
\hline LnY & -2.47 & 0.33 & -2.63 & 0.26 \\
LnK & -3.00 & 0.14 & -3.06 & 0.12 \\
LnL & $-3.61^{* *}$ & 0.04 & $-7.63^{* * *}$ & 0.00 \\
LnEDS & -1.70 & 0.73 & -1.76 & 0.70 \\
LnH & -2.30 & 0.42 & -2.51 & 0.32 \\
$\Delta$ LnY & $-6.63^{* * *}$ & 0.00 & $-6.65^{* * *}$ & 0.00 \\
$\Delta$ LnK & $-7.86^{* * *}$ & 0.00 & $-7.79^{* * *}$ & 0.00 \\
$\Delta$ LnDB & $-5.09^{* * *}$ & 0.00 & $-5.09^{* * *}$ & 0.00 \\
$\Delta$ LnH & $-6.54^{* * *}$ & 0.00 & $-6.54^{* * *}$ & 0.00 \\
\hline
\end{tabular}

Note: $\Delta$ indicates that the first difference is taken. $* *$ and $* * *$ denotes that the series is stationary at $5 \%$ and $1 \%$ significance level, respectively. In the ADF test, the maximum lag length is taken 3 and the optimal lag length is determined using the Schwarz Information Criterion.

According to the findings in Table 3, while the labor force series is stationary at the level values $(I(0))$, the other series are stationary at the first difference $(I(1))$. So the series are not stationary at same levels. Since the series are stationary at different levels, it is not possible to examine the cointegration relationship between these series by Engle and Granger (1987) or Johansen (1988) cointegration tests. In such cases, the cointegration relationship between the series can be examined by the Bounds Testing developed by Pesaran, Shin and Smith (2001), the long and short term relationships can be examined by ARDL method and the causality relationships by the method of Toda and Yamamoto (1995) instead of Granger (1969).

\section{Cointegration Test}

In this study, since some of the series are determined to be $I(0)$ and some of them to be $I(1)$, the cointegration relationships between the series are examined with the Bounds Testing developed by Pesaran, Shin and Smith (2001). The model used in the Bounds Testing adapted to this study is:

$$
\begin{aligned}
\Delta L n Y_{t}=\beta_{0}+\sum_{k=1}^{m_{1}} & \beta_{1 k} \Delta L n Y_{t-k}+\sum_{k=0}^{m_{2}} \beta_{2 k} \Delta L n K_{t-k}+\sum_{k=0}^{m_{3}} \beta_{3 k} \Delta L n L_{t-k}+\sum_{k=0}^{m_{4}} \beta_{4 k} \Delta L n E D S_{t-k} \\
& +\sum_{k=0}^{m_{5}} \beta_{5 k} \Delta L n H_{t-k}+\alpha_{1} L n Y_{t-1}+\alpha_{2} L n K_{t-1}+\alpha_{3} L n L_{t-1}+\alpha_{4} L n E D S_{t-1}+\alpha_{5} \operatorname{LnH}_{t-1}+e_{t}
\end{aligned}
$$

Here, $m_{1}, m_{2}, m_{3}, m_{4}$ and $m_{5}$ are optimum lag lengths and can be estimated by Akaike Information Criteria. In the Bounds Testing, Equation (10) is estimated, constraints are applied on the coefficients that come from one period lagged of the level values of the series and an F test is performed. When the obtained $F$ statistics is greater than the upper limit critical value, it is decided that there is a cointegration relationship between the series. When the obtained F statistics is less than the lower limit value, there is no cointegration relationship between the series. If the obtained $F$ statistics falls between the lower and upper limit values, it indicates uncertainty. (Akel \& Gazel, 2014, p. 31). Hypotheses of the Bounds Testing performed in this study are:

$H_{0}: \alpha_{1}=\alpha_{2}=\alpha_{3}=\alpha_{4}=\alpha_{5}=0 \quad$ No cointegration.

$H_{1}: \alpha_{1} \neq \alpha_{2} \neq \alpha_{3} \neq \alpha_{4} \neq \alpha_{5} \neq 0 \quad$ Cointegration exists.

In the study, Bounds Testing is conducted and the results obtained presented in Table 4. 
Table 4. Results of Cointegration Test

\begin{tabular}{ccccccc}
\hline & \multicolumn{5}{c}{ Criticial Bounds Values } \\
\cline { 2 - 8 } & \multicolumn{7}{c}{$\mathbf{I}(\mathbf{0})$ Bounds } & $\mathbf{1 \%}$ & $\mathbf{1 0} \%$ & $\mathbf{I}(\mathbf{1})$ Bounds \\
\cline { 2 - 8 } F- Stat. & $\mathbf{1 0 \%}$ & $\mathbf{5 \%}$ & $\mathbf{5 \%}$ & $\mathbf{1 \%}$ \\
\hline $3.28^{* *}$ & 1.63 & 1.86 & 2.37 & 2.75 & 3.05 & 3.6 \\
\hline
\end{tabular}

Note: ${ }^{* *}$ denotes cointegration at $5 \%$ significance level.

According to the results in Table 4, there is a cointegration relationship between economic growth, investment, labor force, external debt and human capital series at $5 \%$ significance level. In other words, these series move together in the long run and in the model estimations to be made with the level values of these series, spurious regression problem will not be encountered (Engle, \& Granger, 1987, p. 254). When cointegration relationship between series is determined, long and short term analysis can be carried out (Lim, \& McAleer, 2001, p. 1611).

\section{Long Term Analysis}

When the cointegration relationship is analyzed by the Bounds Testing method, long-term analysis is carried out with ARDL method (Davidescu, 2015, p. 41). For this purpose, Model (13) is used:

$L n Y_{t}=\beta_{0}+\sum_{i=1}^{m_{1}} \beta_{1 i} \operatorname{LnY} Y_{t-i}+\sum_{i=0}^{m_{2}} \beta_{2 i} L n K_{t-i}+\sum_{i=0}^{m_{3}} \beta_{3 i} L n L_{t-i}+\sum_{i=0}^{m_{4}} \beta_{4 i} L n E D S_{t-i}+\sum_{i=0}^{m_{5}} \beta_{5 i} L n H_{t-i}+u_{t}$

In the study, long-term analysis is conducted by ARDL method and the findings are reported in Table 5 .

Table 5. Results of Long Term Analysis

\begin{tabular}{cllc}
\hline Variable & Coefficient & t-stat. & Prob. \\
\hline LnK & $0.31^{* * *}$ & 5.58 & 0.00 \\
LnL & $0.27^{* * *}$ & 17.27 & 0.00 \\
LnEDS & $0.13^{* * *}$ & 4.33 & 0.00 \\
LnH & $0.46^{* * *}$ & 12.56 & 0.00 \\
$\mathrm{D}_{1980}$ & $-0.10^{* *}$ & -2.05 & 0.04 \\
$\mathrm{D}_{1989}$ & $-0.24^{* * *}$ & -10.13 & 0.00 \\
$\mathrm{D}_{1994}$ & $-0.24^{* * *}$ & -3.76 & 0.00 \\
$\mathrm{D}_{2001}$ & -0.03 & -0.58 & 0.56 \\
$\mathrm{D}_{2008}$ & -0.05 & -1.37 & 0.18 \\
\hline \multicolumn{5}{c}{ Descriptive Statistics } \\
\hline $\mathrm{R}^{2}=0.99$ & \multicolumn{4}{c}{ LL $=398.35(0.00)$} & $\mathrm{DW}=2.23$ \\
$\chi_{\mathrm{BG}}^{2}=1.64(0.19)$ & $\chi_{\mathrm{BPG}}^{2}=11.00(0.92)$ & $\chi_{\mathrm{JB}}^{2}=2.96(0.22)$ & $\chi_{\mathrm{RR}}^{2}=0.007(0.93)$ \\
\hline
\end{tabular}

Note: $*, * *$ and $* * *$ indicates significance of the coefficients at $10 \%, 5 \%$ and $1 \%$, respectively. $L L$ : Log Likelihood statistics. $\chi_{B G}^{2}$ : Breusch-Godfrey autocorrelation test. $\chi_{B P G}^{2}$; Breusch-Pagan-Godfrey heteroscedasticity test. $\chi_{J B}^{2}$; Jarque-Bera normality test. $\chi_{R R}^{2}$; Ramsey-Reset model specification test.

According to the findings in Table 5, 1\% increase in fixed capital stock raised per capita income in Turkey by $0.31 \%$ in the period of $1970-2016$. This result indicates that one of the most important ways to increase economic growth in the country is to increase investments and it is very important in this respect. Keeping other factors constant, when labor force in Turkey increased by 1\% in 1970-2016 period, GDP increased by $0.27 \%$. This result implies that the production and national income in Turkey is quite sensitive to labor force. The fact that coefficient of capital is greater than that of labor indicates that the dominant strategy in Turkey is capital-intensive production in the related period. A $1 \%$ increase in Turkey's external debt stock in this period inclines national income by $0.13 \%$ on average. This result provides evidence that the foreign debts received are partly used efficiently. However, the low coefficient is noteworthy. This suggests that the foreign debts received are used in areas such as consumption expenditures and closing public budget deficits in the short term, rather than investments that increase long-term economic growth. It is seen that $1 \%$ increase in human capital raised national income in Turkey with a quite high rate like $0.46 \%$ on average. This is important as it reveals that the main source of economic growth is increasing the quality and productivity of the labor force through education. It is beneficial for policy makers to pay particular attention to this point and to allocate more shares from national income to education. Looking at the dummy variables; it is seen that the coefficients of all dummy variables are negative. Normally, the economic liberalization process initiated in 1980 would be expected to affect economic growth positively, but the coefficient was negative due to the military coup of 
September 12, 1980 and the martial law announced later. Similarly, in 1989, it is expected that free capital movement accelerates economic growth, but the war between Iraq and Kuwait in 1990 and the I. Gulf War started by the intervention of the US to Iraq significantly dropped the exports of Turkey to this region and the economy was negatively affected. It is already known and expected that 1994, 2001 and 2008 crises adversely affect economic growth. Of the reliability tests presented in the below part of table, $R^{2}$ shows that the model has the power to explain the changes in national income as high as $99 \%$, DW and $\chi_{B G}^{2}$ tests indicates there is no autocorrelation in estimations, $\chi_{B P G}^{2}$ demonstrates there is no heteroscedasticity in estimations. $\chi_{J B}^{2}$ reveals that the error terms of the estimation have normal distribution and, therefore, $\mathrm{t}$ and $\mathrm{F}$ tests are reliable. $\chi_{R R}^{2} t$ est proves that there is no model specification error. That is, long term analyses are reliable.

\section{Short Term Analysis}

When the cointegration relationship is tested by Bounds Testing method, short-term analysis is also carried out by ARDL method (Davidescu, 2015, p. 41). Model used for this purpose is:

$$
\begin{gathered}
\Delta L n Y_{t}=\delta_{0}+\sum_{i=1}^{m_{1}} \delta_{1 i} \Delta L n Y_{t-i}+\sum_{i=0}^{m_{2}} \delta_{2 i} \Delta L n K_{t-i}+\sum_{i=0}^{m_{3}} \delta_{3 i} \Delta L n L_{t-i}+\sum_{i=0}^{m_{4}} \delta_{4 i} \Delta L n E D S_{t-i}+ \\
+\sum_{i=0}^{m_{5}} \delta_{5 i} \Delta L n H_{t-i}+\delta_{6} E C T_{t-1}+v_{t}
\end{gathered}
$$

Here, $E C T_{t-1}$ is error correction term. The fact that the coefficient of this term is negative and statistically significant shows that the error correction mechanism of the model operates, that is, the deviations occurred in the short run between the series that move together in the long term disappear and the series converges again to the long term equilibrium relationship. This generates additional evidence that the long-term analysis results are reliable (Tari, 2012, p. 436). In the study, short term analysis is conducted by ARDL method and the findings are reported in Table 6.

Table 6. Results of Short Term Analysis

\begin{tabular}{cllc}
\hline Variable & Coefficient & t-stat. & Prob. \\
\hline$\Delta$ LnK $_{\mathrm{t}}$ & $0.44^{* * *}$ & 13.53 & 0.00 \\
$\Delta \mathrm{LnK}_{\mathrm{t}-1}$ & $0.06^{* *}$ & 2.44 & 0.00 \\
$\Delta \mathrm{LnL}_{\mathrm{t}}$ & 0.18 & 0.42 & 0.67 \\
$\Delta \mathrm{LnEDS}_{\mathrm{t}}$ & 0.003 & 0.06 & 0.94 \\
$\Delta \mathrm{LnH}_{\mathrm{t}}$ & $0.18^{* * *}$ & 6.65 & 0.00 \\
$\mathrm{ECT}_{\mathrm{t}-1}$ & $-0.57^{* * *}$ & -7.22 & 0.00 \\
\hline \multicolumn{1}{c}{ Descriptive Statistics } & $\mathrm{DW}=2.23$ \\
\hline $\mathrm{R}^{2}=0.99$ & $\overline{\mathrm{R}}^{2}=0.99$ & $\mathrm{LL}=398.35(0.00)$ & $\chi_{\mathrm{RR}}^{2}=0.007(0.93)$ \\
\hline$\chi_{\mathrm{BG}}^{2}=1.64(0.19)$ & $\chi_{\mathrm{BPG}}^{2}=11.00(0.92)$ & $\chi_{\mathrm{JB}}^{2}=2.96(0.22)$ & $\mathrm{L}$
\end{tabular}

Note: *,** and $* * *$ indicates significance of the coefficients at $10 \%, 5 \%$ and $1 \%$, respectively. LL: Log Likelihood statistics. $\chi_{B G}^{2}$ : Breusch-Godfrey autocorrelation test. $\chi_{B P G}^{2}$; Breusch-Pagan-Godfrey heteroscedasticity test. $\chi_{J B}^{2}$; Jarque-Bera normality test. $\chi_{R R}^{2}$; Ramsey-Reset equation specification test.

According to the findings in Table 6 , the coefficient of error correction term $(E C T)$ is negative and statistically significant. In this case, the error correction mechanism of the model operates. In other words, deviations occurred in the short run between the series that move together in the long run disappears and the series converges again to the long-run equilibrium relationship. This result supports the reliability of the long-term analysis. Looking at the coefficients of the variables; it is observed that capital stock and human capital support economic growth in the short term, and labor force and external debts have no significant effect on economic growth in the short term. 


\section{Causality Test}

In the causality test developed by Toda and Yamamoto (1995), the level values of the series can be analyzed and, by this way, as much information as possible can be included. Thus, it is more powerful than the Granger causality test. In the Toda-Yamamoto causality test, the optimum lag length $(p)$ is firstly determined by a VAR model estimated by the level values of the series. Then, the highest degree of integration of the series (the difference that they become stationary; $d \max$ ) is added to this $\mathrm{p}$ lag length. Then, the following models are estimated with $(p+d \max )$ lag lenght ${ }^{4}$ :

$$
\begin{aligned}
Y_{t} & =\sum_{i=1}^{p+d_{\max }} \alpha_{i} Y_{t-i}+\sum_{i=1}^{p+d_{\max }} \beta_{i} X_{t-i}+\varepsilon_{t} \\
X_{t} & =\sum_{i=1}^{p+d_{\max }} \gamma_{i} X_{t-i}+\sum_{i=1}^{p+d_{\max }} \delta_{i} Y_{t-i}+\epsilon_{t}
\end{aligned}
$$

After Equation (13) and Equation (14) are estimated, constraints are applied to the coefficients from $d \max$ and a Wald test is performed. Test hypotheses for equation (13) are:

$H_{0}$ : No causality relationship from $X$ to $Y$

$H_{1}$ : There is a causality relationship from $X$ to $Y$

In the hypotheses to be created for equation (13), $X$ and $Y$ will be replaced. In this study, the results of the lag length determination obtained from VAR model estimated by the level values of the series are reported in Table 7.

Table 7. Results of Optimum Lag Length Determination Process

\begin{tabular}{ccccccc}
\hline Lag & LogL & LR & FPE & AIC & SC & HQ \\
\hline 1 & 352.70 & 505.70 & 0.002 & -15.00 & -13.78 & -14.55 \\
2 & 431.64 & 117.49 & 0.001 & -17.51 & -15.26 & -16.68 \\
$\mathbf{3}$ & $\mathbf{4 9 0 . 8 6}$ & $\mathbf{7 4 . 3 6 9 0 8 *}$ & $\mathbf{0 . 0 0 4 *}$ & $\mathbf{- 1 9 . 1 0}$ & $\mathbf{- 1 5 . 8 3 *}$ & $\mathbf{- 1 7 . 9 0 *}$ \\
4 & 519.87 & 29.68 & 0.004 & $-19.29 *$ & -14.99 & -17.71 \\
\hline
\end{tabular}

Note: LR: sequential modified LR test statistic (each test at 5\% level); FPE: Final prediction error; AIC: Akaike information criterion; SC: Schwarz information criterion; HQ: Hannan-Quinn information criterion.

According to the findings in Table 7, optimum lag length is 3 according to LR, FPE, SC and HQ information criteria. The inverse characteristic roots graph showing that the VAR model with 3 lag lengths is stable is presented in Figure 8.

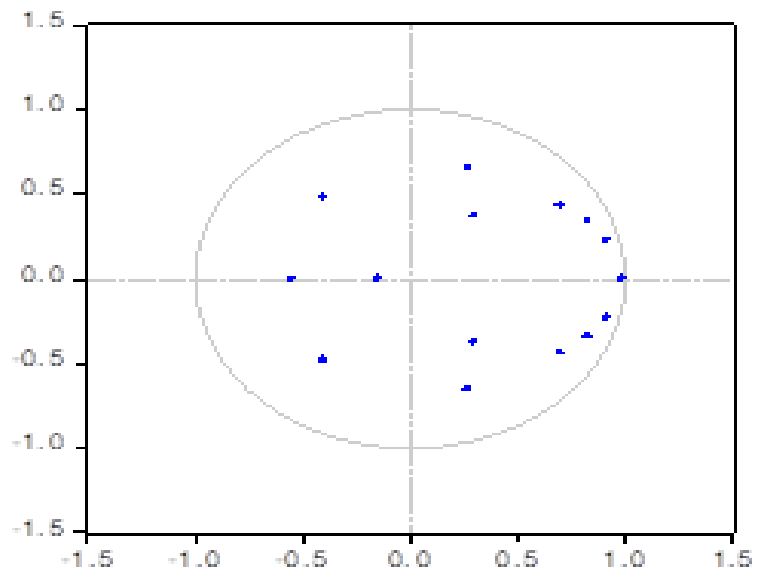

Figure 8. Inverse Roots of AR Characteristic Polynomial 
In Figure 8, the fact that all inverse characteristic roots remain in the unit circle shows that the obtained VAR model is stable. The presence of autocorrelation and heteroscedasticity problems in the 3 lagged VAR model is also tested and the results are reported in Table 8.

Table 8. Findings of Autocorrelation and Heteroscedasticity Tests

\begin{tabular}{ccc}
\hline & Autocorrelation Test & \\
Lag & Test Stat. & Prob. \\
\hline 1 & 17.72 & 0.85 \\
2 & 30.29 & 0.21 \\
3 & 30.05 & 0.22 \\
\hline & Heteroskedasticity Test & \\
Chi-Squre Test Stat. & Degree of Freedom & Prob. \\
\hline 412.60 & 435 & 0.77 \\
\hline
\end{tabular}

According to the findings in Table 8, there is no autocorrelation and heteroscedasticity problems in 3 lagged VAR model. For all these reasons, optimum lag length $(p=3)$ is reliable. In the unit root test, since it is seen that the series become stationary when the first differences are taken, $d \max =1$. For this reason, $p+d \max =3+1=4$ is taken and Toda-Yamamoto causality test is performed over this lag length, the findings are reported in Table 9.

Table 9. Results of Causality Test

\begin{tabular}{ccc}
\hline Direction of Causality & Chi-Squre Test Stat. & Prob. \\
\hline $\operatorname{Ln} K \rightarrow \operatorname{Ln} Y$ & 6.31 & 0.17 \\
$\operatorname{Ln} Y \rightarrow \operatorname{LnK}$ & 4.93 & 0.29 \\
$\operatorname{Ln} L \rightarrow \operatorname{Ln} Y$ & $13.53^{* * *}$ & 0.00 \\
$\operatorname{Ln} Y \rightarrow \operatorname{Ln} L$ & 0.63 & 0.95 \\
$\operatorname{Ln} E D S \rightarrow \operatorname{Ln} Y$ & $8.54^{*}$ & 0.07 \\
$\operatorname{Ln} Y \rightarrow \operatorname{Ln} E D S$ & 2.69 & 0.61 \\
$\operatorname{Ln} H \rightarrow \operatorname{Ln} Y$ & 6.85 & 0.14 \\
$\operatorname{Ln} Y \rightarrow \operatorname{Ln} H$ & 6.54 & 0.16 \\
$\operatorname{Ln} L \rightarrow \operatorname{LnK}$ & $8.16^{*}$ & 0.08 \\
$\operatorname{Ln} L \rightarrow \operatorname{LnH}$ & $13.12^{* *}$ & 0.01 \\
$\operatorname{Ln} D B \rightarrow \operatorname{Ln} H$ & $14.59^{* * *}$ & 0.00 \\
\hline
\end{tabular}

Note: *, ** and *** shows that there is a causality relationship from first variable two second variable at $10 \%, 5 \%$ and $1 \%$ significance levels, respectively.

In order to follow the causality relationships obtained in Table 9 more easily, Figure 9 is created:

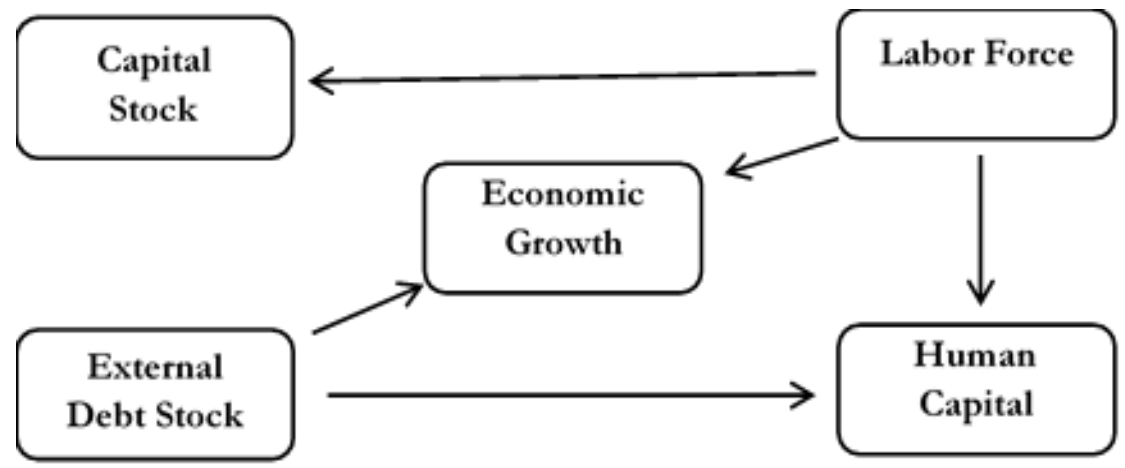

Figure 9. Causality Relationships between the Variables

According to the findings in Table 8 and Figure 9; while one-way causality relationship exists from labor and external debt stock to economic growth (national income), no causality relationship from fixed capital stock and human capital to economic growth is identified. Causality relationship from labor force to economic growth implies that labor-intensive producing strategy is valid in Turkey. Causality relationship from external debt stock to economic growth indicates that external debts received are used in a way that positively affecting the country's economic growth. Although this is pleasing, there is no causality relationship from the external debt stock to the fixed capital stock, suggesting that the foreign 
debts received are used for consumption expenditures and refinancing of existing debts, not for investment expenditures. The fact that there is no causality relationship from fixed capital stock to economic growth demonstrates that fixed capital stock in Turkey is not at the level that can affect economic growth. Not having a causality relationship from human capital to economic growth indicates that human capital (the share of education in national income) in Turkey is insufficient and production is carried out by raw labor.

Causality relationship from labor force to fixed capital stock implies that more machinery and equipment are being purchased as labor force increases, which is important in order for the law of decreasing return on labor to fail. Causality relationship from labor force to human capital shows that the public and private sector allocates more resources to education due to the increasing labor force (population). Causality relationship from external debt stock to human capital reveals that a part of the borrowings is used in the improvement of human capital, which is a pleasing case for Turkey.

\section{Conclusion and Suggestions}

High and stable economic growth is the aim of all countries and, for this, domestic production factors (labor, capital, natural resources and entrepreneurship) is used first. When these are insufficient, external borrowing and imports of production factors (immigration, imports of machinery and equipment, attracting foreign direct investment, employing qualified experts, imports of natural resources and intermediate goods etc.) are needed. At this point, it is of great importance that the external debt received should be utilized effectively and in productive areas. In this study, impacts of external debt on economic growth in Turkey are examined using econometric methods for 1970-2016 period. At the end of Bounds Testing; it is observed that there is a statistically significant cointegration relationship between economic growth, investment, labor, external debt and human capital series, that is, these series move together in the long term. In the long run analysis carried out by ARDL method, it is determined that $1 \%$ increase in fixed capital stock, labor force, external debt stock and human capital improves national income by $\% 0,31$, $\% 0,27, \% 0,13$ and $\% 0,46$, respectively, in 1970-2016 period. In the causality analysis, while one-way causality relationship is revealed from labor force and external debt stock to economic growth, no causality relationship can be identified from fixed capital stock and human capital to economic growth. The results obtained from this study are consistent with the findings of Adegbite, Ayadi and Ayadi (2008), Gül, Kamac1 and Konya (2012), Daud, Ahmad and Azman-Saini (2013), Özer (2014), Ijirshar, Joseph and Godoo (2016), Kutlu and Yurttagüler (2016), Kamac1 (2016) and Jilenga, Xu and Gondje-Dacka (2016). The results are also similar to Bilginoğlu and Aysu (2008) in terms of the relationship between external debt stock and economic growth, but they differ in terms of labor force and fixed capital stock.

Based on the findings obtained from this study; it can be concluded that external debts in Turkey have slightly positive impact on economic growth and, in order to increase this impact, debt received should be used in investment expenditures and in areas to improve human capital instead of consumption expenditures and closing the budget deficit. Also, starting from the fact that improvements in the capital stock have positive effects on economic growth; it is worth noting that public and private sector investment expenditures should be increased. Considering the labor intensive structure of production and depending on the result that increases in labor force positively affects economic growth in Turkey, it is clear that young population of the country should be made productive. Finally; based on the fact that the variable that most affects economic growth among the data used in the study is human capital; it can be stated that it is absolutely necessary to focus on health and education investments that would increase the productivity of the labor force in the country. In this regard, internship opportunities to students with the cooperation of public and private sector, vocational training courses to unemployed individuals, tax incentives to companies employing new labor force, reducing the costs of private health services and enabling employees to reach higher quality health services in a shorter time will be useful.

\section{Ethical Declaration}

In the writing process of the study titled "Relationship between Economic Growth External Debt: Application to Turkey", scientific, ethical and citation rules were followed; No falsification was made on the collected data and this study was not sent to any other academic media for evaluation. Since the data set is used in this article, ethics committee approval is not required. 


\section{References}

Adegbite, E. O., Ayadi, F. S., \& Ayadi, O. F. (2008). The impact of Nigeria's external debt on economic development. International Journal of Emerging Markets, 3(3), 285-301.

Agir, H. (2016). The causality analysis of the relationship between external borrowing and economic growth in Turkey. Selcuk University Journal of Social and Economic Research, 32, 204-221.

Akan, Y., \& Kanca, O. C. (2015). The relationship between external debt, economic growth and inflation in Turkey: var approach (1980-2013). Hacettepe University, Journal of Faculty of Economics and Administrative Sciences, 33(3), 122.

Altin, S. (2003). Evaluating foreign sources in terms of Turkey's economic development. (Master Thesis) Süleyman Demirel University Institute of Social Sciences, Isparta.

Aysu, Y. (2011). The foreign debt problem of Turkey after 1980 and its impact on economic growth. (Master Thesis) Adnan Menderes University, Institute of Social Sciences, Aydin.

Bilginoglu, M. A., \& Aysu, A. (2008). The effects of external debts on economic growth: the case of Turkey. Journal of Erciyes University Faculty of Economics and Administrative Sciences, 31, 1-23.

Boopen, S., Kesseven, P., \& Ramesh, D. (2007). External debt and economic growth: a vector error correction approach. International Journal of Business Research, 7(5), 75-91.

Brueckner, M., \& Lederman, D. (2017). Inequality and GDP per capita: the role of initial income. Access address: http://pubdocs.worldbank.org/en/755201504498011731/inequality-and-growth-3-september-2017.pdf, Date of access: 14.01.2018.

Ceylan, S., \& Durkaya, M. (2011). The relation between external debt and economic growth: an asymmetric cointegration analysis. Journal of Economics Business and Finance, 26(301), 91-115.

Cunningham, R. T. (1993). The effects of debt burden on economic growth in heavily indebted nations. Journal of Economic Development, 18(1), 115-126.

Cogurucu, I., \& Coban, O. (2011). The relationship between external debt and economic growth: the case of turkey (1980-2009). Karamanoglu Mehmetbey University Journal of Social and Economic Research, 13(21), 133-149.

Daud, S. N. M., Ahmad, A. H., \& Azman-Saini, W. N. W. (2013). Does external debt contribute to Malaysia economic growth? Ekonomska Istrą̌wanja-Economic Research, 26(2), 51-68.

Davidescu, A. A. (2015). Bounds test approach for the long run relationship between shadow economy and official economy: an empirical analysis for Romania. Journal of Applied Quantitive Methods, 10(1), 36-47.

Dickey, D. A., \& Fuller, W. A. (1981). Distribution of the estimators for autoregressive time series with a unit root. Econometrica, 49, 1057-1072.

Dritsaki, C. (2013). Causal nexus between economic growth, exports and government debt: the case of Greece. Procedia Economics and Finance, 5, 251-259.

World Bank (2018). What is external debt? Access address: https://datahelpdesk.worldbank.org /knowledgebase/articles/474124-what-is-external-debt, Date of access: 03.01.2018.

Ejigayehu, D. A., \& Persson, J. (2013). The effect of external debt on economic growth. a panel data analysis on the relationship between external debt and economic growth. Access address: http://www.divaportal.org/smash/get/diva2:664110/Fulltext01.pdf,N. Date of access: 26.01.2018.

Elmas Arslan, G. (2013). Economic growth, development and Income distribution. Hitit University Journal of Social Sciences Institute, 6(2), 45-52.

Engle, R. F., \& Granger, C. W. J. (1987). Co-integration and error correction: representation, estimation, and testing. Econometrica, 55(2), 251-276.

Eratas, F., \& Basci Nur, H. (2013). The relationship between external debt and economic growth: the example of emerging markets economies. Marmara University Journal of Economics and Administrative Sciences, XXXV(II), 207-230.

Erdogan, S., \& Canbay, S. (2016). A theoretical investigation about the relationship of economic growth and research \& development (R\&D) expenditure. Journal of Social Sciences of Mus Alparslan University, 4(2), 29-44.

Evgin, T. (2000). Our foreign debts from past to present. General Directorate of Economic Research, Research Review Series, N. 26, Ankara.

Granger, C. W. J. (1969). Investigating causal relations by econometric models and cross-spectral methods. Econometrica, 37, 424-438.

Gujarati, D. N., \& Porter, D. C. (2012). Basic econometrics. Istanbul: Literatur Publications.

Gul, E., Kamaci, A., \& Konya, S. (2012). Effect of external debt on growth: the case of central Asian republics and Turkey. International Conference on Eurasian Economies, 11-13 October, Almaty-Kazakhstan.

Gurdal, T., \& Yavuz, H. (2015). The relationship of external borrowing and economic growth in Turkey: the period of 1990-2013. Journal of Finance, 168, 154-169.

Guvel, E. A. (2011). Economic growth theories. dynamics of the wealth of nations. Karahan Bookstore, Adana.

IMF (2018). Debt and reserve related indicators of external vulnerability. Access address: https://www.imf.org/external/np/pdr/debtres/, Date of access: 26.01.2018.

Ijirshar, V. U., Joseph, F., \& Godoo, M. (2016). The relationship between external debt and economic growth in Nigeria. International Journal of Economics \& Management Sciences, 6(1), 1-5. 
Jilenga, M. T., Xu, H., \& Gondje-Dacka, I. M. (2016). The impact of external debt and foreign direct investment on economic growth: empirical evidence from Tanzania. International Journal of Financial Research, 7(2), 154-162.

Johansen, S. (1988). Statistical analysis of co-integration vectors. Journal of Economic Dynamic and Control, 12, 231-254.

Jones, C. I. (2007). Introduction to economic growth. Literatur Publications, Istanbul.

Jones, C. J. (2016). The facts of economic growth. Handbook of macroeconomics, Volume 2A. Elsevier. Access address: https://web.stanford.edu/ chadj/facts.pdf, Date of access: 13.01.2018.

Kamac1, A. (2016). Effects of external debt on economic growth and inflation: panel co-integration and panel causality analyses. International Journal of Cultural and Social Studies (IntJCSS), 2(1), 165-175.

Kara, M. (2001). External debt dilemma in Turkey's economic growth process. Süleyman Demirel University, Faculty of Economics and Administrative Sciences, 6(1), 95-110.

Karagol, M. (2014). Redefining the production factors in the development process. Journal of Leges Economic and Legal Studies, 1(1), 1-11.

Kesbic, C. Y., Dundar, Ö., \& Devrim, A. (2016). Crowding out effect of public investments on private sector investments: The Turkey example. Dokuz Eylül University, Journal of Faculty of Economics and Administrative Sciences, 31(2), 59-94.

Kirci Cevik, N., \& Cural, M. (2013). Causality between domestic debt, external debt, and economic growth: the case of Turkey over the period 1989-2012. Journal of Finance, 165, 115-139.

Kogar, I. C. (1996). A note on equivalent butce theory and its applicability. Discussion papers 9630, Research and Monetary Policy Department, Central Bank of the Republic of Turkey.

Kozali, J. (2007). External debt problem and the impact of external debt on the growth: Turkish experience (Master Thesis) Dokuz Eylul University Institute of Social Sciences, Izmir.

Kutlu, S., \& Yurttaguler, I. M. (2016). External debt-economic growth relationship in Turkey: a causality analysis for the 1998-2014 Period. Marmara University Journal of Economics and Administrative Sciences, 38(1), 229-248.

Lim, C., \& McAleer, M. (2001). Co-integration analysis of quarterly tourism demand by Hong Kong and Singapore for Australia. Applied Economics, 33, 1599-1619.

Lin, S., \& Sosin, K. (2001). Foreign debt and economic growth. Economics of Transition, 9(3), 635-655.

Lindgren, M. (2008). Documentation for GDP per capita by purchasing power parities for countries and territories. Access address: https://www.gapminder.org/documentation/documentation/Gapdoc001_v9 .pdf, Date of access: 18.01.2018.

Lucas, R. E. (1988). On the mechanics of economic development. Journal of Monetary Economic, 22, 3-32.

Malik, S., Hayat, M. K., \& Hayat, M. U. (2010). External debt and economic growth: empirical evidence from Pakistan. International Research Journal of Finance and Economics, 44, 88-97.

Mankiw, N. G. (2010). Macroeconomics. Efil Bookstore, Ankara.

Mohamed, S. A. E. (2014). Testing the relationship between private savings and economic growth in Bahrain. Global Journal of Commerce and Management Perspective, 4(6), 1-6.

Nwannebuike, U. S., Ike, U. J., \& Onuka, O. I. (2016). External debt and economic growth: the Nigeria experience. European Journal of Accounting Auditing and Finance Research, 4(2), 33-48.

Olcar, A. (2013). Turkey's external debt problem and the effects of the crisis (Master Thesis) Hitit University, Institute of Social Sciences, Corum.

Ozdemir, B. (2009). Foreign debts of the ottoman empire. During the 1854-1954 period. Centennial pillory. 18541914 debt Galata bankers and the ottoman bank accepts ottoman public debt administration of the ottoman public debt administration of the republic of Turkey. Ankara Chamber of Commerce Publication.

Ozer, S. (2014). External debt and economic growth relationship in Turkey: a study on the period 1980-2010. (Master Thesis) Giresun University, Institute of Social Sciences, Giresun.

Ozyildiz, H. (2017). External borrowing and country credit rating. Access Address: http://slideplayer.biz.tr/slide/11831358/, Date of access: 15.01.2018.

Panizza, U., Sturzenegger, F., \& Zettelmeyer J. (2010). International government debt. UNCTAD Discussion Papers, No. 199, Access address: http://unctad.org/en/Docs/osgdp20103_en.pdf, Date of access: 03.01.2018.

Parasiz, I. (2008). Fundamentals of modern macro economy. Ezgi Bookstore, Bursa.

Pesaran, M. H., Shin, Y., \& Smith, R. J. (2001). Bounds testing approaches to the analysis of level relationships. Journal of Applied Econometrics, 16(3), 226-339.

Phillips, P. C. B., \& Perron, P. (1988). Testing for a unit root in time series regression. Biomètrika, 75(2), 336-346.

Romer, P. M. (1986). Increasing returns and long-run growth. Journal of Political Economy, 94, 1002-1037.

Sarac, T. B. ve Yucel, M. H. (2017). External debt and economic growth relationship: Turkey example. Turan-Sam: Turan Strategic Research Center, 9(35), 15-20.

Solow, R. M. (1956). A contribution to the theory of economic growth. The Quarterly Journal of Economics, 70, 65-94.

Tari, R. (2012). Econometrics. Umuttepe Publications, Kocaeli.

CBRT (1989). Resolution 32 on the protection of the value of the Turkish currency. Access address: http://www.tcmb.gov.tr/wps/wcm/connect/8bb1302e-cecc-4ae4-9622-54365f8ee2e1/kambiyo2.pdf? Mod=Ajperes, Date of access: 18.01.2018.

Toda, H. Y., \& Yamamoto, T. (1995). Statistical inference in vector autoregressions with possbly integrated process. Journal of Econometrics, 66, 225-250. 
Topal, M. H., \& Bostan, M. K. (2017). Unemployment in Turkey on external debt effective? II. International Strategic Research Congress, 28 September-1 October 2017, Avantgarde Hotel, Kemer, Antalya.

World Bank (1990). A strategy for managing debt, borrowing and transfer under macroeconomic adjustment: Turkey. Washington D. C.

World Bank (2018a). External debt stocks, total (Dod, current US\$). Access address: https://data.worldbank.org /indicator/DT.DOD.DECT.CD?view=chart, Date of access: 21.01.2018.

World Bank (2018b). GDP growth (annual \%). Access address: https://data.worldbank.org/indicator/NY.GDP. MKTP.KD.ZG?view = chart Date of access: 21.01.2018.

World Bank (2018c). Exports of goods and services (current US\$), Access address: https://data.worldbank. org/indicator/NE.EXP.GNFS.CD?view=chart, Date of access: 21.01.2018.

World Bank (2018d). Interest payments on external debt (\% of GNI), Access address: https://data.worldbank.org/indicator/DT.INT.DECT.GN.ZS?view=chart, Date of access: 21.01.2018.

World Bank (2018e). External debt stocks (\% of exports of goods, services and primary income), Access address: https://data.worldbank.org/indicator/DT.DOD.DECT.EX.ZS?view=chart, Date of access: 21.01.2018.

World Bank (2018f). Tax revenue ( $\%$ of GDP), Access address: https://data.worldbank.org/indicator /GC.TAX.TOTL.GD.ZS?view=chart, Date of access: 21.01.2018.

Yildirim, K., Karaman, D., \& Tasdemir, M. (2009). Macroeconomics. Seckin Publisher, Ankara.

Yüce, G., Akinci, M., \& Yilmaz, O. (2013). The causality relationship between financial development and economic growth: A multi-country time series analysis, Journal of Financial Researches and Studies, 4(8), 111-144.

\section{TÜRKÇE GENIŞ ÖZET}

Kaynakların dünya ülkeleri arasındaki dengesiz dağılımı, ülkeler arasındaki gelişmişlik farkları ve gelişen uluslararası ilişkiler sonucunda ülkelerin iç kaynakları ekonomik büyüme ve kalkınmanın finansmanında yetersiz kalabilmektedir. Gelişmekte olan ülkelerde ekonomik büyümenin hızlandırılması için gerekli olarak görülen yatırımların yurtiçi kaynaklardan karşılanamaması nedeniyle bu ülkelerin dış borçlanmaya olan ihtiyacı giderek artabilmektedir. Bu ihtiyaç, Türkiye ekonomisi için de söz konusudur. Özellikle 1950'li yıllardan sonra doğrudan yabancı sermaye yatırımı, dış borçlanma ve yabancı krediler elde etme konusunda ekonomi politikalarında köklü değişiklikler yaparak dış borçlanma olanaklarını arttıran Türkiye, ekonomik büyüme ve kalkınma hedefini sürdürebilmek için dış kaynak aramaya ve dış borçlanmaya yönelmiştir.

Gerek gelişmiş, gerekse gelişmekte olan ülkelerde ekonomik büyüme ve kalkınmanın finansmanında kullanılan ulusal kaynakların, yani iç tasarrufların önemi büyüktür. Bunlar yetmediğinde ise dış tasarruflar, yani dış borçlar devreye girmektedir. Dolayısıyla, ekonomik büyümenin kaynağı olarak iç ve diş tasarruflar gösterilebilir. Bu bağlamda az gelişmiş ülkelerin ekonomik büyüme ve kalkınmalarını gerçekleştirecek yurtiçi tasarrufların yetersizliği, vergi toplamada etkin yöntemlerin geliştirilememesi, ihracatın düşük düzeyde kalması ve turizm gelirlerinin de az olması, ülkeleri yeni kaynak arayışı içine sokmaktadır ve böyle durumlarda diş borçlanma, kaçınılmaz hale gelmektedir (Bilginoğlu ve Aysu, 2008, s. 1). Özellikle savaş, ekonomik kriz, doğal afet gibi büyük ölçekli sorunlar, ülkelerin dış yardımlara ve dış borçlanmaya olan ihtiyacını daha da artırmaktadır. Devletin ya da bir kamu kuruluşunun dış kaynaklardan fon sağlaması olarak tanımlanan dış borçlanma (Evgin, 2000, s. 15), iktisadi kalkınma süreçlerini devam ettirebilmek amacıyla özellikle gelişmekte olan ülkelerde yoğun bir şekilde kullanılmıştır. Bu anlamda gelişmekte olan ülkelerde iç tasarrufların az olması nedeniyle sermaye, kıt üretim faktörü olarak görülebilmektedir (Karagöl, 2014, s. 6). Ayrıca gelişmekte olan ülkeler, gerekli yatırımları yapabilmeleri için ihtiyaç duydukları yatırım mallarını, ithalat yoluyla karşılayabilmektedirler. İthalat giderlerini karşılayacak olan ihracat gelirlerinin düşük olması sonucu, bu ülkeler bir döviz darboğazı ile karşı karşıya kalabilmekte ve dış borçlanmaya yönelmektedirler (Çural ve Genç, 2017, s. 88).

Alındıkları andan itibaren ülkeye ek kaynak girişi sağlayan dış borçların, verimli alanlarda kullanıldıkları takdirde ekonomik büyüme ve kalkınmanın altyapısını oluşturan sermaye miktarını artırması beklenebilir. Bu bağlamda, artan sermaye miktarı aracilığıla yatırımlar artarak ekonomik büyüme ve kalkınmanın hızlanması sağlanabilecektir (Panizza, Sturzenegger ve Zettelmeyer, 2010, s. 2). Bakıldığında, yüksek ve istikrarlı bir ekonomik büyüme, bütün ülkelerin ortak amacı olup, bu doğrultuda öncelikle yerel üretim faktörleri (emek, sermaye, doğal kaynak ve girişimci) kullanılmakta, bunlar yetmediğinde ise dış ülkelerden borçlanma ve üretim faktörü ithalatı (göç alma, makine ve teçhizat ithalatı, doğrudan yabancı yatırım çekmek, nitelikli uzman istihdamı, doğal kaynak ve aramalı ithalatı gibi) yoluna başvurulmaktadır. Bu noktada, alınan diş borçların verimli değerlendirilmesi ve üretken alanlarda kullanılması büyük önem arz etmektedir. Fakat, alınan dış borçların, verimli alanlarda kullanılmaması durumunda ise ülkeler zor durumda kalabilmektedir. Özellikle dış borç anapara ve faiz ödemeleri ulusal gelir artışından daha fazla 
artış gösterdiğinde, yeniden borçlanma yoluna gidilmesi kaçınılmaz olmaktadır. Ülkeden dışarıya kaynak çıkışını gerektiren bu durum sonucunda ülkenin borç yükü daha da artmakta, büyüme yavaşlamakta ve dolayisıyla refah seviyesi azalmaktadır.

Bu çalşsmada Türkiye'de 1970-2016 döneminde dış borçların, ekonomik büyüme üzerindeki etkileri ekonometrik yöntemler yardımıyla incelenmiştir. Yapılan nedensellik analizinde; işgücü ve dış borç stokundan ekonomik büyümeye doğru tek yönlü nedensellik ilişkisi çıkarken, sabit sermaye stoku ve beşeri sermayeden ekonomik büyümeye doğru herhangi bir nedensellik ilişkisi tespit edilememiştir. Sınır Testi sonucunda; ekonomik büyüme, yatırım, işgücü, dış borç ve beşeri sermaye serileri arasında, istatistiksel olarak anlamlı düzeyinde bir eşbütünleşme ilişkisinin var olduğu, yani bu seriler uzun dönemde birlikte hareket ettikleri görülmüştür. ARDL yöntemiyle gerçekleştirilen uzun dönem analizinde; 1970-2016 döneminde Türkiye'de milli geliri sabit sermaye stokundaki $\% 1$ 'lik artışın ortalama $\% 0,31$, işgücündeki $\% 1$ oranındaki artışın $\% 0,27$, dış borç stokundaki $\% 1$ 'lik artışın $\% 0,13$ ve beşeri sermayedeki $\% 1$ oranındaki artışın \%0,46 oranında artırdığı tespit edilmiştir.

Bu çalışmadan elde edilen bulgulara dayanarak; dış borçların Türkiye'de ekonomik büyümeyi az da olsa olumlu yönde etkilediği, bu etkinin artırılabilmesi için alınan borçların tüketim harcamaları ve bütçe açıklarının kapatılması yerine yatırım harcamaları ve beşeri sermayeyi iyileştirici alanlarda kullanılmasının gerektiği söylenebilir. Ayrıca sermaye stokundaki iyileşmelerin ekonomik büyüme üzerinde olumlu etkisinin tespit edilmiş olmasından hareketle; kamu ve özel sektör yatırım harcamalarının artırılmasının gerektiğini belirtmekte yarar vardır. Türkiye'de üretimin emek yoğun bir yapıya sahip olduğu da göz önünde bulundurularak ve çalışmada işgücündeki artısların ekonomik büyümeyi olumlu yönde etkilediği bulgusuna dayanarak; sahip olunan genç nüfusun üretken hale getirilmesinde büyük yarar olacağ1 açıktır. Son olarak; çalışmada kullanılan veriler arasında ekonomik büyümeyi en fazla etkileyen değişkenin beşeri sermaye olmasından hareketle; mutlaka ülkede işgücünün verimliliğini artırıcı sağlık ve eğitim yatırımlarına ağırlık verilmesinin gerektiği ifade edilebilir. Bu konuda kamu ve özel sektör işbirliği ile öğrencilere sağlanacak staj olanakları, işsiz bireylere sağlanacak meslek edindirme kursları, yeni işgücü istihdam eden firmalara sağlanacak vergisel teşvikler, özel sağlık hizmetlerinin maliyetlerinin düşürülmesi ve erişiminin kolaylaştırılması yoluyla çalışan bireylerin daha kısa sürede ve daha kaliteli sağlık hizmetlerinden yararlanabilmesinin önünü açılması faydalı olacaktır. 